Санкт-Петербургский клинический

научно-практический центр спещиализированных видов медищинской помощи (онкологический) (Россия, Санкт-Петербург)
РОЛЬ ХИРУРГИЧЕСКИХ

ТЕХНОЛОГИЙ В ЛЕЧЕНИИ

ВИРУС-АССОЦИИРОВАННЫХ

ОПУХОЛЕЙ НА ПРИМЕРЕ

ГЕПАТОЦЕЛЛЮЛЯРНОГО РАКА

П.В. Балахнин, А.С. Шмелев, Е.Г. Шачинов

\section{THE ROLE OF SURGICAL TECHNOLOGIES IN THE TREATMENT OF VIRUS-ASSOCIATED TUMORS ON THE EXAMPLE OF HEPATOCELLULAR CARCINOMA}

П.В. Балахнин

Кандидат медицинских наук, врач-хирург, старший научный сотрудник научного отдела, заведующий ОРХМДиЛ, Санкт-Петербургский клинический научно-практический центр специализированных видов медицинской помощи (онкологчческий), 197758, Россия, Санкт-Петербург, пос. Песочный, Ленинградская ул., д. 68 А. E-mail: balabnin_p@mail.ru.

А.С. Шмелев Врач-хирург, ОРХМДиЛ.

Е.Г. Шачинов Научный сотрудник научного отдела, врач-хирург, ОРХМДиЛ.

P.V. Balakhnin

Candidate of Medicine, surgeon, Senior Researcher of Scientific Department, Head of Department of Interventional Radiology, St. Petersburg Clinical Research Center of Specialized Types of Care (Oncology), 197758, Russia, St. Petersburg, pos. Pesochniji, Leningradskaya ul., 68A.

E-mail: balabnin_p@mail.ru.

A.S. Shmelev Surgeon, Department of Interventional Radiology.

E.G. Shachinov Researcher of Scientific Department, Surgeon, Department of Interventional Radiology.

Гепатоцеллюлярный рак (ГЦР) является наиболее сложной, но в то же время и наиболее интересной с точки зрения хирургического лечения вирус-ассоциированной опухолью. У больных с вирус-ассоциированным ГЦР цирроз печени необходимо рассматривать как конкурирующее заболевание и учитывать этот факт при определении тактики лечения. ГЦР абсолютно резистентен к химиотерапии и лучевой терапии (включая стереотаксическую), поэтому хирургические (резекция и трансплантация печени) и рентгенохирургические (трансартериальная химиоэмболизация и чрескожная энергетическая абляция) методы лечения являются единственными методами эффективной терапии. В последние два десятилетия достигнут колоссальный прогресс в развитии этих технологий, что позволило значительно увеличить выживаемость пациентов с очень ранней, ранней и промежуточной стадиями ГЦР согласно классификации BCLC.

ключевые слова: гепатоцеллюлярный рак, рак печени, вирусный гепатит, цирроз печени, вирус-ассочиированные опухоли, ВГВ, ВГС, НВV, НCV, химиоэмболизащия, аблящия. 
Hepatocellular cancer (HCC) is the most difficult, but at the same time, the most interesting cancer from the point of view of surgical treatment of virus-associated tumor. In patients with virus-associated HCC, liver cirrhosis should be considered as a competing disease and this fact should be taken into account when determining treatment strategy. HCC is absolutely resistant to chemotherapy and radiation therapy (including stereotactic), therefore surgical (resection and liver transplantation) and IR (transarterial chemoembolization and percutaneous energy-based ablation) treatment methods are the only methods of effective therapy. In the past two decades, dramatic progress has been reached in the development of these technologies, which has significantly increased the survival of patients with very early, early and intermediate stages of HCC according to the BCLC classification.

Keywords: hepatocellular carcinoma, liver cancer, viral hepatitis, liver cirrbosis, virus-associated tumors, HBV, HCV, chemoembolization, ablation.

\section{І. ВВЕДЕНИЕ}

1. Онкогенные вирусы и вирус-ассоциированные опухоли

И нфекционные возбудители играют важную роль в этиологии многих злокачественных опухолей. Из 14 миллионов новых случаев рака, выявленных в 2012 году (по данным GLOBOCAN 2012), 2,2 миллиона (15,7\%) были непосредственно связаны с различными видами хронических инфекций (табл. 1) [1]. При этом основная роль в инфекционном канцерогенезе принадлежит различным ДНК- и РНК-содержащим вирусам (64,2\%), в то время как на долю бактериальных и паразитарных агентов приходится только $35,4 \%$ и 0,4\% опухолей, соответственно (табл. 2) [1].

На сегодняшний момент известно о существовании восьми семейств вирусов, которые Междуна- родным Агентством по Изучению Рака (International Agency for Research of Cancer, IARC) отнесены к разряду высококанцерогенных для человека (табл. 3) [2]. К ним, в порядке очередности их открытия, относятся вирус Эпштейна-Барра (EBV (HHV4)), вирус гепатита $\mathrm{B}(\mathrm{HBV})$, человеческий Т-клеточный лимфотропный вирус 1 типа (HTLV-1), вирус иммунодефицита человека 1 типа (HIV-1), вирусы папиллом человека (HPV), вирус гепатита $\mathrm{C}(\mathrm{HCV})$, человеческий герпесвирус 8 типа, ассоциированный с саркомой Капоши (KSHV (HHV8)), и полиомавирус клеток Меркеля (MCV). Эти восемь семейств вирусов ответственны за развитие более чем 20 видов злокачественных опухолей, на долю которых приходится около 10\% всех онкологических заболеваний (табл. 4) [1].

Канцерогенез является длительным и многоэтапным процессом, а вирусы могут принимать в нем

\section{Распределение инфекционно-ассочиированных онкологических заболеваний в зависимости от геограбического региона, а такжсе уровня человеческого и индустриального развития по даннъм Pluтmеr M. et al. [1] в модификачии (GLOBOCAN 2012).}

\begin{tabular}{|c|c|c|c|}
\hline Показатель & $\begin{array}{c}\text { Число впервые } \\
\text { выявленных } \\
\text { злокачественных } \\
\text { опухолей }\end{array}$ & $\begin{array}{c}\text { Число злокачественных } \\
\text { опухолей, связанных } \\
\text { с инфекционными } \\
\text { агентами }\end{array}$ & $\begin{array}{c}\text { Доля инфекционно- } \\
\text { ассоциированных } \\
\text { онкологических } \\
\text { заболеваний (\%) }\end{array}$ \\
\hline \multicolumn{4}{|c|}{ Регион } \\
\hline Африка южнее Сахары & 630000 & 200000 & 31,3 \\
\hline Восточная Азия & 4900000 & 1100000 & 22,8 \\
\hline Центральная Азия & 1500000 & 290000 & 19,4 \\
\hline Латинская Америка & 1100000 & 160000 & 14,4 \\
\hline Северная Африка & 540000 & 70000 & 13,1 \\
\hline Европа & 3400000 & 250000 & 7,2 \\
\hline Океания & 160000 & 7600 & 4,9 \\
\hline Северная Америка & 1800000 & 72000 & 4,0 \\
\hline \multicolumn{4}{|c|}{ Индекс человеческого развития } \\
\hline Очень высокий & 5700000 & 430000 & 7,6 \\
\hline Высокий & 2200000 & 290000 & 13,2 \\
\hline Средний & 5200000 & 1200000 & 23,0 \\
\hline Низкий & 940000 & 240000 & 25,3 \\
\hline \multicolumn{4}{|c|}{ Уровень индустриального развития } \\
\hline Более развитые регионы & 7900000 & 730000 & 9,2 \\
\hline Менее развитые регионы & 6200000 & 1400000 & 23,4 \\
\hline ВСЕГО & 14000000 & 2200000 & 15,7 \\
\hline
\end{tabular}


Таблица 2.

Вклад различных видов возбудителей в развитие инфекционно-ассочиированных злокачественных опухолей по данным Pluтmеr M. et al. [1] u Lunn R.M. et al. [2] в модификации (GLOBOCAN 2012)

\begin{tabular}{|c|c|c|c|c|c|}
\hline & $\begin{array}{c}\text { Вид } \\
\text { инфекционного агента }\end{array}$ & $\begin{array}{l}\text { Число впер- } \\
\text { вые выявлен- }\end{array}$ & $\begin{array}{r}\text { Распреде } \\
\text { холей }\end{array}$ & $\begin{array}{l}\text { ение опу- } \\
\text { о полу }\end{array}$ & $\begin{array}{c}\text { Вклад возбудителя в } \\
\text { общую заболеваемость }\end{array}$ \\
\hline & & $\begin{array}{c}\text { чественных } \\
\text { опухолей }\end{array}$ & $\mathbf{M}$ & ж & $\begin{array}{c}\text { ассоциированными } \\
\text { опухолями (\%) }\end{array}$ \\
\hline I & Вирусы & 1407000 & 590000 & 817000 & 64,2 \\
\hline 1 & $\begin{array}{l}\text { Вирусы папиллом человека / } \\
\text { Human papillomaviruses (HPV) }\end{array}$ & 640000 & 66000 & 570000 & 29,5 \\
\hline 2 & $\begin{array}{l}\text { Вирус гепатита В / Hepatitis B } \\
\text { virus (HBV) }\end{array}$ & 420000 & 300000 & 120000 & 19,2 \\
\hline 3 & $\begin{array}{l}\text { Вирус гепатита C / Hepatitis C } \\
\text { virus (HCV) }\end{array}$ & 170000 & 110000 & 55000 & 7,8 \\
\hline 4 & $\begin{array}{l}\text { Вирус Эпштейна-Барра / } \\
\text { Epstein-Barr virus } \\
\text { (EBV (HHV4)) }\end{array}$ & 120000 & 80000 & 40000 & 5,5 \\
\hline 5 & $\begin{array}{l}\text { Человеческий герпесвирус } \\
8 \text { типа, ассоциированный с } \\
\text { саркомой Капоши / Кароsi } \\
\text { sarcoma-associated herpesvirus } \\
\text { (KSHV (HHV)) }\end{array}$ & 44000 & 29000 & 15000 & 2,0 \\
\hline 6 & $\begin{array}{l}\text { Полиомавирус клеток } \\
\text { Меркеля / Merkel cell } \\
\text { polyomavirus (MCV) }\end{array}$ & 10000 & н/д & н/д & 0,3 \\
\hline 7 & $\begin{array}{l}\text { Человеческий Т-клеточный } \\
\text { лимфотропный вирус } 1 \text { типа } \\
\text { / Human T-cell lymphotropic } \\
\text { virus type } 1 \text { (HTLV-1) }\end{array}$ & 3000 & 1700 & 1200 & 0,1 \\
\hline 8 & $\begin{array}{l}\text { Вирус иммунодефицита } \\
\text { человека } 1 \text { типа / Human } \\
\text { immunodeficiency virus type } 1 \\
\text { (HIV-1) }\end{array}$ & - & - & - & - \\
\hline II & Бактерии & 770000 & 500000 & 270000 & 35,4 \\
\hline 1 & $\begin{array}{l}\text { Хеликобактер пилори / } \\
\text { Helicobacter pylori }\end{array}$ & 770000 & 500000 & 270000 & 35,4 \\
\hline III & Паразиты & 8300 & 5720 & 2670 & 0,4 \\
\hline 1 & $\begin{array}{l}\text { Кровяная шистосома / } \\
\text { Schistosoma haematobium }\end{array}$ & 7000 & 4900 & 2200 & 0,3 \\
\hline 2 & $\begin{array}{l}\text { Беличья двуустка и Двууст- } \\
\text { ка китайская / Opisthorchis } \\
\text { viverrini and Clonorchis } \\
\text { sinensis }\end{array}$ & 1300 & 820 & 470 & 0,1 \\
\hline BCI & & 2200000 & 1100000 & 1100000 & 100 \\
\hline
\end{tabular}




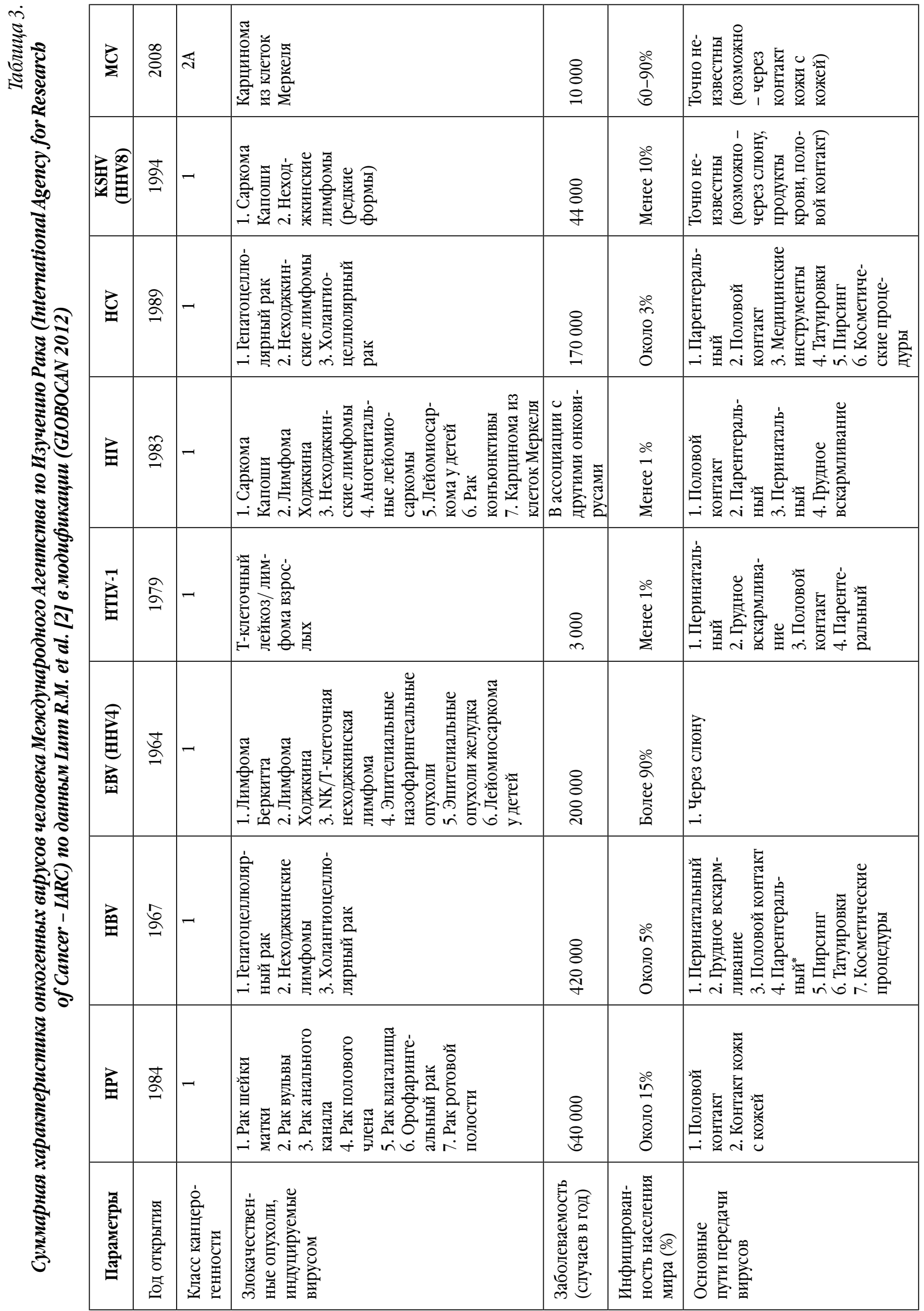




\begin{tabular}{|c|c|c|c|c|c|}
\hline 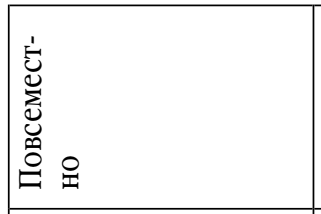 & 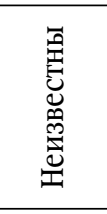 & 采 & 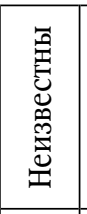 & 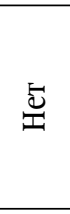 & 竧 \\
\hline 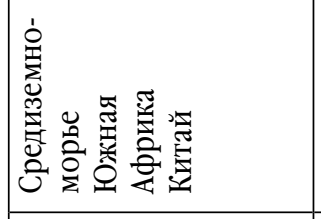 & 孚 & 总 & 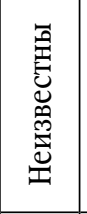 & 总 & 咅 \\
\hline 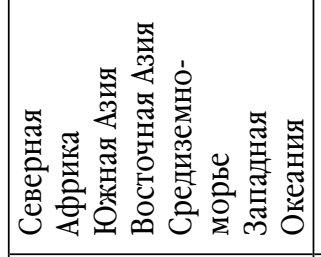 & 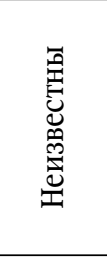 & 总 & 亲 & $\frac{\pi}{8}$ & 竧 \\
\hline 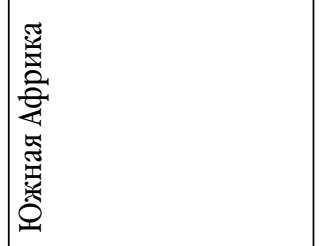 & 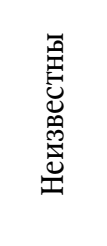 & 总 & 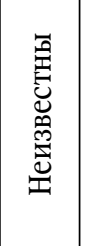 & 舟 & 总 \\
\hline 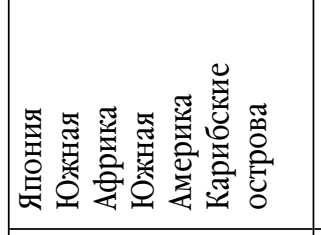 & 孚 & 孚 & 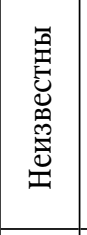 & 番 & 萦 \\
\hline$\frac{\Sigma_{\tilde{z}}}{2}$ & 采 & 总 & 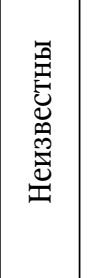 & 莺 & 竧 \\
\hline 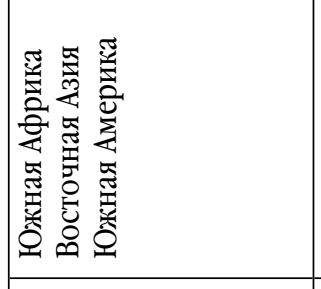 & $\approx$ & 䎹 & $\stackrel{\pi}{\sharp}$ & $\stackrel{\pi}{9}$ & 舟 \\
\hline 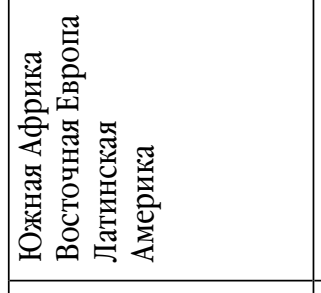 & 采 & 串 & $\stackrel{\pi}{\sharp}$ & 采 & $\stackrel{\mathscr{A}}{4}$ \\
\hline 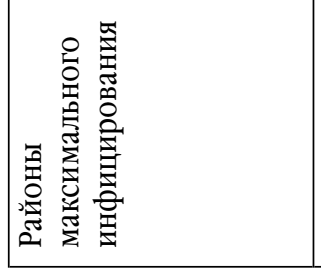 & 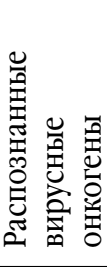 & & 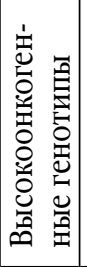 & & 递 \\
\hline
\end{tabular}

участие на разных стадиях в зависимости от их семейства и вида. Они могут интегрироваться в геном хозяина, приводя к инищиащии опухолевого процесса, а могут действовать и путем модуляции сигнальных путей, влияющих на регуляцию клеточной пролиферации или апоптоза (промоция опухолей) [1-3]. Кроме того, вирусы способны участвовать в возникновении рака не только прямым, но и опосредованным способом, например, посредством стимулирования иммуносупрессии, что характерно для HIV. Установление этиологии и механизмов канцерогенеза ряда вирус-ассоциированных опухолей привело к существенному улучшению скрининга и ранней диагностики этих заболеваний в группе риска, а также внедрению их эффективной первичной и вторичной профилактики [3]. Однако, остается не до конца изученным вопрос о том, существуют ли особенности лечения (лекарственного, лучевого, хирургического или комбинированного) вирус-ассоциированных опухолей по сравнению с опухолями другой этиологии. В этой работе мы рассмотрим особенности хирургического лечения вирус-ассоциированных опухолей на примере одной из них.

2. Гепатоцеллюлярный рак (ГЦР) как наиболее сложный пример вирус-ассоциированной опухоли

Без преувеличения можно говорить о том, что ГЦР является наиболее сложной, но в то же время и наиболее интересной с точки зрения рассматриваемой темы вирус-ассоциированной опухолью. Связано это с несколькими причинами. Во-первых, среди вирус-ассоциированных опухолей ГЦР имеет самую высокую заболеваемость и смертность (табл. 4) $[1,4,5]$. Во-вторых, ГЦР это единственная опухоль, в возникновении которой принимают участие несколько различающихся между собой семейств вирусов: ДНК-содержащие HBV, РНК-содержащие HCV и РНК-содержащие вирусы гепатита D (HDV) [6]. Эти вирусы имеют разные территории распространения, пути передачи, степень вирулентности и канцерогенности, а также разные возможности профилактики и лечения. В связи с этим HBV-ассоциированный ГЦР и HCV-ассоциированный ГЦР, по сути, являются разными заболеваниями, с разным клиническим течением и прогнозом [6]. В-третьих, что не характерно для других вирус-ассоциированных опухолей, сочетание нескольких хронических вирусных инфекций (HBV-HDV-инфекции, HBV-HCV-инфекции 
Вклад вирусов в канщерогенез различных типов вирус-ассощиированных опухолей

Таблища 4. по данным Plummer M. et al. [1] в.модификации (GLOBOCAN 2012)

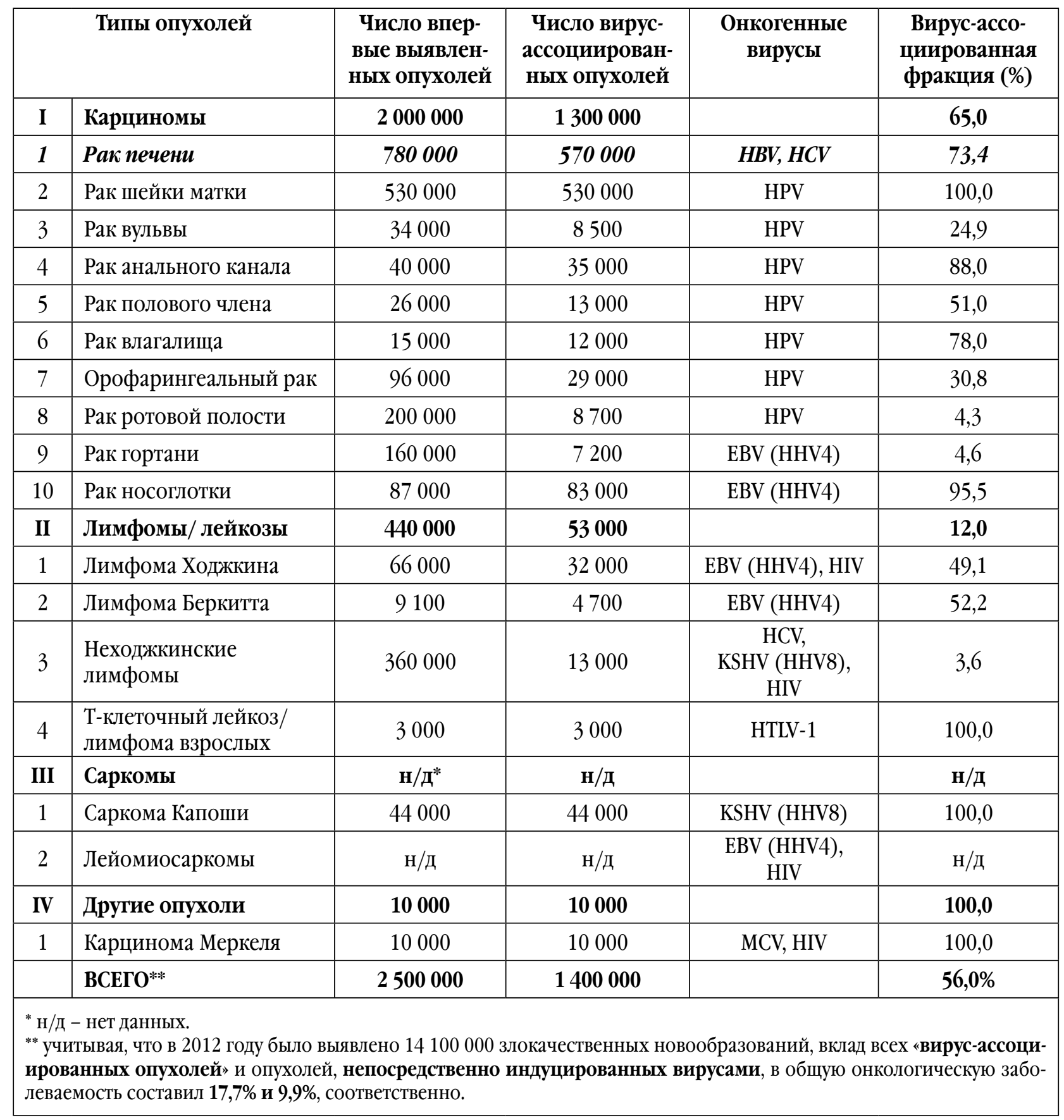

или HBV-HDV-HCV-инфекции) обладает выраженным синергетическим канцерогенным эффектом, и накладывает свой отпечаток на прогноз и тактику лечения этой категории больных [7]. В-четвертых, вирусные гепатиты не только индуцируют гепатоканцерогенез, но и являются причиной хронического воспаления паренхимы печени, постепенно приводящего к фиброзу и циррозу [6]. При этом цирроз печени является самостоятельным и конкурирующим с ГЦР заболеванием, а прогноз для жизни пациента с ГЦР на фоне цирроза определяется той патологией, которая выражена в большей степени или прогрессирует быстрее [6, 7]. В-пятых, ранняя диагностика ГЦР крайне затруднена в связи с тем, что он возникает не в здоровой паренхиме, а в одном из множества диспластических узлов, длительно маскирующих злокачественную трансформацию клеток [6]. Кроме того, для ГЦР характерен синхронный гепатоканцерогенез и нередко на момент установления диагноза в печени выявляется многоузловое поражение, делающее выполнение резекции нецелесообразным или технически невозможным. В-шестых, цирротическое 
поражение паренхимы на фоне которого развивается ГцР не позволяет использовать общепринятые методы противоопухолевой терапии, эффективные для лечения других вирус-ассоциированных опухолей. Так, на сегодняшний день, несмотря на проведение более 100 рандомизированных исследований, не существует ни одной известной схемы химиотерапии (не считая таргетной), способной хоть сколько-нибудь увеличить продолжительность жизни больных по сравнению с симптоматическим лечением [6, 7]. Несмотря на то, что ГЦР достаточно чувствителен к лучевой терапии, последняя (в том числе и стереотаксическая), как и химиотерапия, является малоэффективной, что обусловлено низкой радиорезистентностью печеночной паренхимы, пораженной циррозом [6, 7]. В-седьмых, говоря о хирургических методах лечения ГЦР, нужно помнить о том, что печень является непарным, но в то же время жизненно-необходимым органом, с которым можно сравнить разве что только головной мозг. Это делает принципиально невозможным выполнение операций, направленных на полное удаление органа (что широко применяется, например, при раке шейки матки), а любые резекции должны выполняться с учетом сохранения функциональной полноценности остающейся паренхимы. Кроме того печень содержит пять видов сосудистых структур (артерии, ветви воротной вены, желчные протоки, дренирующая система печеночных вен и лимфатические сосуды), анатомические особенности которых нужно учитывать во время оперативного вмешательства. И наконец, даже радикально проведенное хирургическое лечение (в том числе трансплантация печени), не устраняет причин развития рака. Персистирующая вирусная инфекция часто приводит к метахронному канцерогенезу и появлению новых узлов ГЦР $[4,6,7]$. Все эти многочисленные особенности возникновения и развития вирус-ассоциированного ГЦР, безусловно, накладывают свой отпечаток на тактику лечения этого заболевания. Целью работы является рассмотреть современные представления о возможностях и особенностях хирургического лечения ГЦР, как наиболее сложной вирус-ассоциированной опухоли. При этом под хирургическими методами лечения мы будем понимать не только резекцию и трансплантацию печени, но и все виды рентгенохирургических (интервенционно-радиологических) вмешательств, используемых в клинической практике [4].

\section{II. ГЦР КАК ГЛОБАЛЬНАЯ ПРОБЛЕМА ЗДРАВООХРАНЕНИЯ}

\section{1. Заболеваемость и смертность в мире}

Рак печени занимает шестое место в структуре онкологической заболеваемости и четвертое в структуре онкологической смертности в мире [5]. Так как заболеваемость раком печени у мужчин в 2,8 раза выше, чем у женщин (рис. 1), у мужчин он является пятой

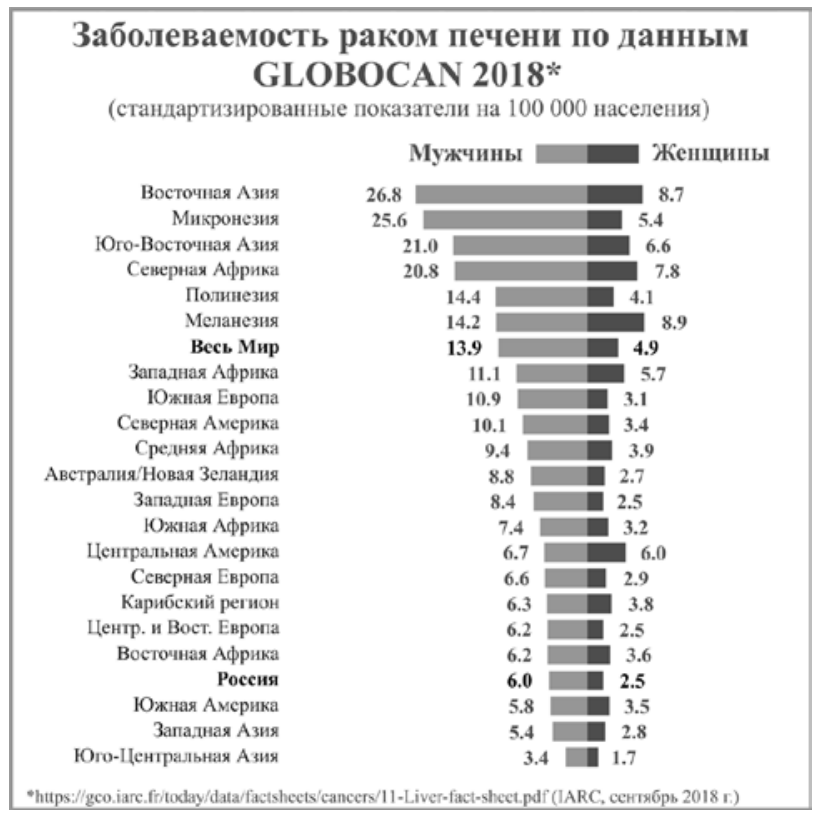

Рис. 1. Заболеваемость раком печени в различных регионах в зависимости от пола по данным GLOBOCAN 2018

по распространенности злокачественной опухолью (после рака лёгкого, простаты, колоректального рака и рака желудка) но занимает второе место в структуре онкологической летальности, уступая только раку легкого [5]. По данным GLOBOCAN 2018 в текущем году раком печени заболеет около 841080 человек и погибнет от этого заболевания - 781631 пациентов [5].

ГЦР представляет более 90\% первичного рака (около 10\% приходится на холангиоцеллюлярный рак и другие опухоли) и в настоящее время является глобальной проблемой всемирной системы здравоохранения. Частота его увеличивается по мере старения населения во всех популяциях, достигая пика в возрасте около 70 лет. Несмотря на очевидные успехи, достигнутые в лечении ГЦР в последние годы, общий прогноз заболевания остается неблагоприятным - соотношение смертность/заболеваемость составляет 0,91 (рис. 2) [6, 7]. Высокая смертность от ГЦР обусловлена резистентностью опухоли к химиотерапии, частым развитием ряда серьезных осложнений связанных с циррозом, а также поздней диагностикой заболевания, когда курабельные методы лечения становятся недоступными. По всему миру около 76\% случаев ГЦР вызваны вирусами $\mathrm{HBV}$ и HCV, в то время как на остальные этиологические факторы (алкоголь, афлатоксины, метаболический синдром, диабет, ожирение, неалкогольную жировую болезнь печени, наследственные заболевания, синдром Бада-Киари и другие неизвестные причины) приходится только $24 \%$ случаев. В связи с этим для ГЦР характерен выраженный географический дисбаланс, отражающий уровень инфицированности населения $\mathrm{HBV}$ и $\mathrm{HCV}$ в различных регионах планеты. Самые высокие показатели заболеваемости регистрируются в Восточной Азии (более 50\% случаев приходится на 


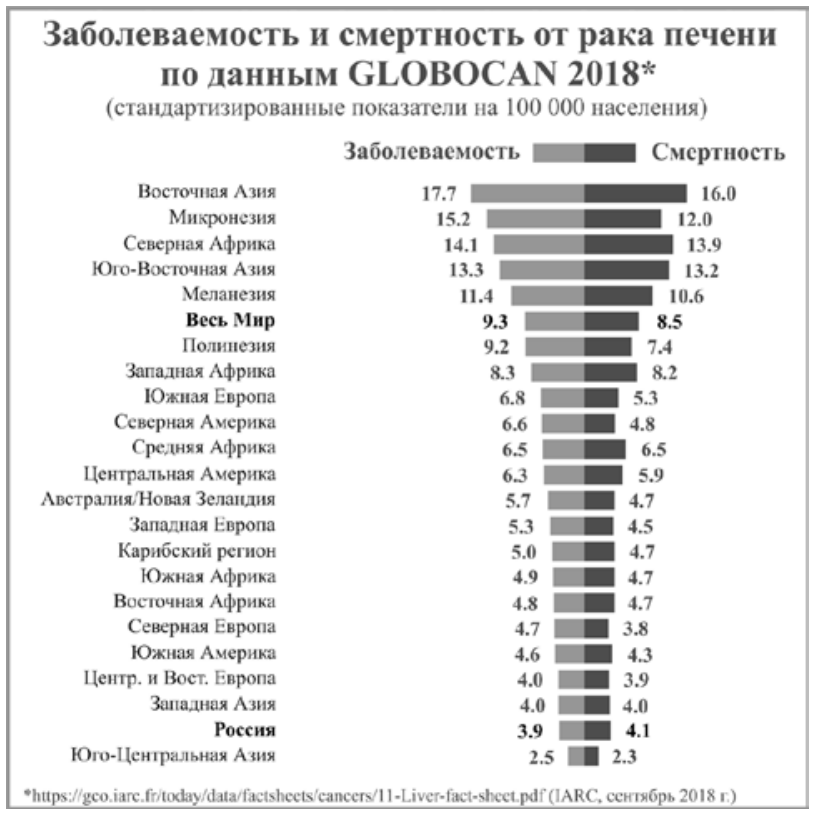

Рис. 2. Заболеваемость и смертность от рака печени в различных регионах по данным GLOBOCAN 2018

Китай) и в странах Африки, расположенных южнее Сахары, что суммарно составляет около 85\% ГЦР (рис. 1,2 ) [8]. При этом наибольшая заболеваемость, составляющая 93,7 на 100000 населения характерна для Монголии, где преобладает смешанное HBV-HDVинфицирование (рис. 3) [8]. В Европе заболеваемость несколько ниже за исключением Южной Европы (Италия, Испания, Португалия, Греция, Сербия, Словения и Хорватия), где число заболевших мужчин составляет 10,9 на 100000 населения (рис. 1). В последние 30 лет заболеваемость ГЦР как в Европе, так и по всему миру неуклонно растет. В частности, в период с 1990 по 2015 год число вновь выявляемых случаев ГЦР увеличилось на 75\% [6]. Ожидается, что эта тенденция сохранится до 2030 года, главным образом из-за изменения структуры возрастных групп населения и роста населения планеты в целом [7]. Смертность от ГЦР также продолжает увеличиваться во всех странах мира. Так в США число смертей с 1990 по 2004 год выросло на 40\%, в отличие от общего показателя смертности от рака, который за тот же период снизился примерно на 18\% [7]. Рост заболеваемости в США обусловлен в первую очередь увеличением числа пациентов страдающих циррозом печени, на фоне длительной хронической HCV-инфекции, а также притоком большого числа HBV-инфицированных мигрантов из әндемичных районов планеты. Согласно прогнозам ASCO в США к 2030 году ГЦР станет третьим по смертности онкологическим заболеванием, обойдя рак молочной железы, колоректальный рак и рак предстательной железы [7].

\section{2. Заболеваемость и смертность в России}

На первый взгляд проблема ГЦР не является первоочередной для Российской Федерации. По данным GLOBOCAN 2018 заболеваемость ГЦР в России состав- ляет 3,9 на 100000 населения, что соответствует 19 месту в структуре заболеваемости, или 10349 впервые выявленных случаев в 2018 году. [9]. Однако крайне настораживает высокая смертность от ГЦР, значительно превышающая заболеваемость (4,1 на 100000 населения, или 11192 человека), что смещает рак печени уже на 9 место в структуре онкологической летальности $[9,10]$. По различным данным от 800 до 1000 случаев ГЦР ежегодно диагностируется только после смерти пациентов [9, 11]. Это, по всей видимости, связано с отсутствием в России системы скрининга пациентов группы высокого риска, отсутствием онкологической настороженности у клиницистов (в первую очередь гепатологов и инфекционистов), а также с отсутствием элементарных знаний об основах диагностики ГЦР среди специалистов лучевой диагностики. Еще более удручающей выглядит картина в разрезе заболеваемости и смертности среди мужской половины населения России. Так, у мужчин заболеваемость находится на 12 (5946 случаев в год), а смертность - уже на 6 месте (6432 случая), располагаясь после рака легкого, колоректального рака, рака желудка, предстательной и поджелудочной железы [9]. Кроме того, в России, как и в других странах мира, заболеваемость ГЦР неуклонно растет. Так, по данным Каприна А.Д. с соавт. общее число заболевших раком печени в 2007 году составляло 6298 случаев, а в 2017 году он был диагностирован уже у 8796 человек, что соответствует росту заболеваемости на 39,7\% в течение 10 лет [11]. Дальнейший рост заболеваемости ГЦР, как и в США, следует ожидать из-за увеличения численности населения с длительно существующей (и чаще всего не диагностированной) HCV-инфекцией, вероятность существования которой высока среди людей, рожденных в период с 1940 года по 1960 год. [7]. Кроме

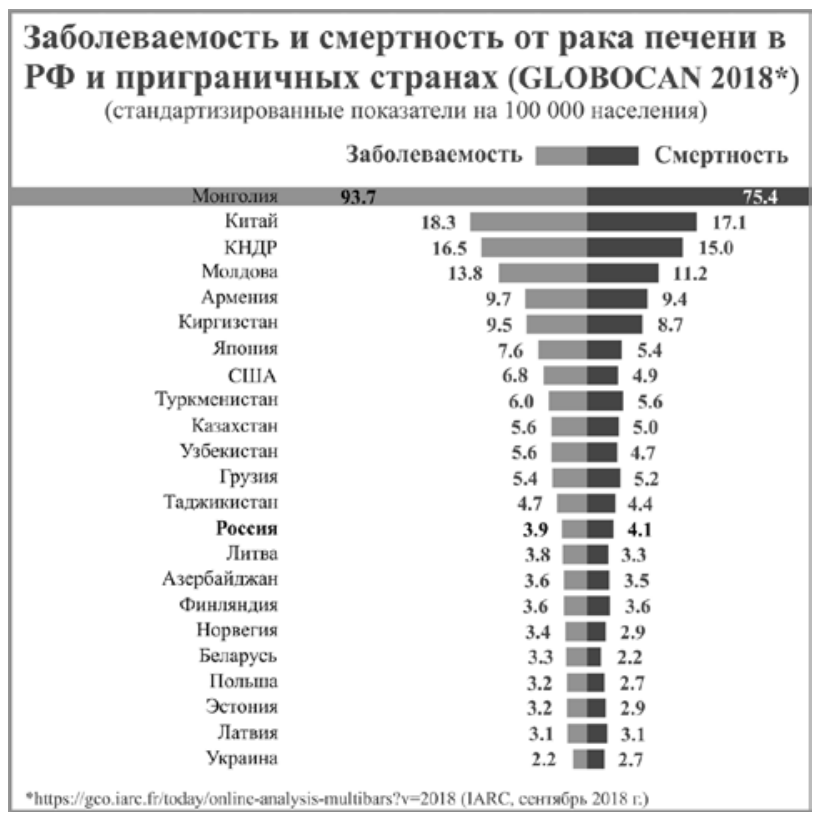

Рис. 3. Заболеваемость и смертность от рака печени в России и приграничных странах по данным GLOBOCAN 2018 
того, число впервые выявленных случаев ГЦР будет увеличиваться в связи с миграцией в Россию людей из стран ближнего зарубежья, где заболеваемость раком печени в несколько раз превышает Российскую (рис. 3).

\section{III. РОЛЬ ВИРУСОВ В ГЕПАТОКАНЦЕРОГЕНЕЗЕ}

Существует устойчивое мнение о том, что вирусы играют ведущую роль в заболеваемости ГЦР только в странах с низкими индексами человеческого и индустриального развития. Однако, как видно из данных, опубликованных в этом году Maucort-Boulch D. et al., это далеко не так (табл. 5) [12]. В то время как общая фракция вирус-ассоциированного ГЦР в мире составляет 76\%, в менее развитых странах этот показатель доходит до 79\%, что не намного выше уровня в 66\%, наблюдаемого в странах с высокими индексами человеческого и индустриального развития [12]. На самом деле разница между отдельными регионами заключается только в преобладании того или иного семейства вирусов (HBV, HBV-HDV, HCV или их сочетания) и общего числа инфицированных. Так, подавляющее число случаев ГЦР в развивающихся странах связано с хронической HBV-инфекцией (67\%), а вклад HCV составляет только $12 \%$. В то же время в развитых странах наблюдается зеркальная картина, при которой ведущая роль в канцерогенезе ГЦР принадлежит HCV (43\%), а фракция HBV-ассоциированных опухолей не превышает 23\% [13].

\section{HBV-индуцированный канцерогенез}

HBV представляет собой частично двухцепочный ДНК-содержащий вирус, реплицирующийся путем обратной транскрипции [13]. В отличие от ретровирусов, таких как HIV, интеграция вирусной ДНК в геном хозяина не является необходимым этапом в жизненном цикле HBV. Хотя геномная интеграция, носящая случайный характер, иногда может приводить к прямой онкогенной активации и развитию ГЦР, чаще всего она способствует возникновению общей генетической нестабильности, являющейся причиной появления большого числа атипичных клонов со временем. Существуют серьезные доказательства того, что $H B V$-индуцированный гепатоканщерогенез возникает задолго до начала формирования фиброза и цирроза печени. Это объясняет ограниченную эффективность противовирусной терапии для снижения риска развития ГЦР у пациентов с длительным анамнезом заболевания $[6,7]$.

Вирусный гепатит В является одним из наиболее распространённых инфекционных заболеваний во всем мире с числом хронически инфицированных превышающим 400 миллионов человек и ежегодно уносящим более 1 миллиона жизней $[12,13]$. Самые высокие показатели заболеваемости отмечаются в странах, расположенных к Югу от Сахары и в Восточной Азии, где инфицировано 5-10\% взрослого населения. Для заражения HBV достаточно от 1 до 10 вирионов, при этом вирус передается различными пу-

Фракции HBV - и HCV-индуцированных опухолей в общей структуре заболеваемости ГЦР Таблица 5. в зависимости от региона и уровня развития по данным Maucort-Boulch D. et al. [12] в модификации (GLOBOCAN 2012).

\begin{tabular}{|c|c|c|c|c|c|c|c|}
\hline \multirow[b]{2}{*}{ Показатель } & \multirow{2}{*}{$\begin{array}{c}\text { Общее } \\
\text { число } \\
\text { случаев } \\
\text { ГЦР }\end{array}$} & \multicolumn{2}{|c|}{ HBV } & \multicolumn{2}{|c|}{ HCV } & \multicolumn{2}{|c|}{ ВСЕГО } \\
\hline & & Число & $\begin{array}{c}\text { Доля, } \\
\%\end{array}$ & Число & $\begin{array}{c}\text { Доля, } \\
\%\end{array}$ & Число & $\begin{array}{c}\text { Доля, } \\
\%\end{array}$ \\
\hline \multicolumn{8}{|c|}{ Регион } \\
\hline Северная Европа & 6400 & 510 & 8 & 1800 & 28 & 2310 & 36 \\
\hline Остальная Европа & 57000 & 11000 & 20 & 23000 & 40 & 34000 & 60 \\
\hline Северная Америка & 33000 & 2400 & 7 & 19000 & 58 & 21400 & 65 \\
\hline Латинская Америка & 30000 & 6800 & 22 & 13000 & 44 & 19800 & 66 \\
\hline Африка южнее Сахары & 39000 & 19000 & 49 & 8100 & 21 & 27100 & 70 \\
\hline $\begin{array}{l}\text { Австралия } \\
\text { и Новая Зеландия }\end{array}$ & 1960 & 1000 & 51 & 410 & 21 & 1410 & 72 \\
\hline $\begin{array}{l}\text { Западная } \\
\text { и Центральная Азия }\end{array}$ & 48000 & 22000 & 46 & 14000 & 29 & 36000 & 75 \\
\hline Восточная Азия & 540000 & 370000 & 68 & 58000 & 11 & 428000 & 79 \\
\hline Северная Африка & 20000 & 1800 & 9 & 16000 & 80 & 17800 & 89 \\
\hline \multicolumn{8}{|c|}{ Степень развития } \\
\hline Более развитые & 190000 & 44000 & 23 & 82000 & 43 & 126000 & 66 \\
\hline Менее развитые & 585000 & 390000 & 67 & 71000 & 12 & 461000 & 79 \\
\hline ВСЕГО & 775000 & 434000 & 56 & 153000 & 20 & 587000 & 76 \\
\hline
\end{tabular}


тями, в том числе парентеральным, половым, а также при оказании медицинских и косметологических услуг (пирсинг, татуировки и т.д.) низкого качества [12, 13]. В последние десятилетия риск инфицирования HBV значительно сократился за счет повышения стандартов гигиены, скрининга продуктов крови и введения профилактической вакцинации. Согласно опубликованным данным, вакцинация новорожденных против HBV в Азии, начатая в середине 1980-х годов, способствовала снижению заболеваемости ГЦР на 70-85\% [13]. Однако, главным путем инфицирования во всем мире остается вертикальная (внутриутробная или перинатальная, в том числе и с грудным молоком) передача HBV от матери к ребенку. Даже несмотря на перинатальную иммунизацию и лечение аналогами нуклеозидов около 5-10\% младенцев, рожденных от сильно виремичных матерей инфицируются HBV в раннем послеродовом периоде $[12,13]$. Последнее объясняет большое число хронически инфицированных людей, так как при заражении в возрасте до 2 лет в более чем 90\% случаев инфекция приобретает хронический характер. Напротив, инфицирование подростков или взрослых в значительной степени приводит к острым инфекциям, заканчивающимся выздоровлением, а хронизация болезни отмечается только в 1-5\% случаев.

Страны, где распространенность HBV-инфекции превышает 2\%, имеют повышенные показатели заболеваемости и смертности от ГЦР. У носителей HBV риск развития ГЦР в течение жизни составляет 10-25\%, что в 15-20 раз выше, чем в здоровой популяции $[6,7,12,13]$. У пациентов с циррозом вероятность развития ГЦР составляет 2\% в год, достигая $30 \%$ в течение жизни [6]. Среди инфицированных дополнительными факторами, увеличивающими риск развития ГЦР, являются мужской пол, монголоидная или экваториальная раса, пожилой возраст, генотип вируса С, длительность инфицирования, высокие уровни репликации вирусов, наличие цирроза, коинфекции (HCV, HDV или HIV), а также употребление алкоголя, курение и контакт с афлатоксинами [13]. Совокупный риск развития ГЦР в возрасте от 30 до 70 лет оценивается в 87\% для тех, кто постоянно позитивен относительно HBsAg и HBeAg, в 12\% для тех, кто постоянно позитивен только к HBsAg и 1\% для тех, кто отрицателен к HBsAg [13]. Важной особенностью HBV в отличие от других причин гепатоканцерогенеза является то, что он в 20\% случаев приводит к развитию ГЦР без признаков цирроза, что значительно затрудняет скрининг в этой группе больных.

На сегодняшний день хроническая HBV-инфекция не может быть полностью излечена. Несмотря на это, риск развития HBV-ассоциированного ГЦР можно существенно снизить с помощью противовирусной терапии аналогами нуклеозидов (Ламивудин, Телбивудин, Тенофир и др.) [13]. Подавление репликации вирусов способствует снижению 5-летней заболеваемости ГЦР в 4 раза по сравнению с контрольной группой (с 13,7\% до 3,7\%, соответственно) [7]. Однако необходимо помнить о том, что эффективная противовирусная терапия уменьшает, но не исключает риск развития ГЦР каку пациентов с ииррозом, так и без него.

\section{HCV-индуцированный канцерогенез}

HCV представляет собой одноцепочный РНКсодержащий вирус, реплицирующийся в цитоплазме гепатоцитов, не кодируя при этом онкопротеинов и не интегрируясь в геном клетки-хозяина [13]. Поэтому HCV-индуцированный канцерогенез является опосредованным и связан с влиянием вируса на дерегуляцию различных клеточных механизмов, включая усиление пролиферации гепатоцитов и стеатоз, индукцию вирусного воспаления и окислительного стресса, вызывающих геномные мутации и геномную нестабильность, а также путем повреждения митохондрий и индукции иммунного ответа хозяина [13].

На сегодняшний момент в мире заражено около 170 миллионов человек, 35 0000-500 000 из которых ежегодно погибает от прогрессирующего цирроза или ГЦР, развивающихся в течение нескольких десятилетий хронической инфекции [7]. Распространенность инфекции сильно варьирует от 0,5-2,5\% в Северной Европе и 1,8\% в США до 3\% в сельских районах Румынии. Наиболее пострадавшей страной является Египет (Северная Африка), где число инфицированных достигает 18\%, что связано с заражением населения во время проведения вакцинации от шистосомоза с использованием многоразовых стеклянных шприцев в 1960-е годы [7, 13].

На сегодняшний момент HCV передается преимущественно парентерально при употреблении внутривенных наркотиков, половым путем, а также при оказании медицинских и косметологических услуг низкого качества. Однако в развитых странах подавляющее большинство инфицированных HCV людей (более 75\%) относятся $\kappa$ поколению «бебибумеров», рожденных с 1940 по 1960 год в Европе и с 1945 по 1965 год в США [7]. Эти люди были инфицированы еще до открытия вируса $\mathrm{HCV}$ и разработки современных методов его диагностики и скрининга продуктов крови [7]. В частности в США люди, родившиеся между 1945-1965 годами, составляют 80\% всех инфицированных с общей распространенностью инфекции в этой когорте 2,6\%, что в 6 раз выше, чем в общей популяции [7]. Передача от матери к ребенку наблюдается крайне редко. В отличие от HBV риск длительной персистенции или развития хронической HCV-инфекции у детей ниже, чем у взрослых. При заражении взрослых заболевание протекает бессимптомно и в $80 \%$ случаев переходит в хроническую форму вирусного гепатита, который у 20\% пациентов заканчивается развитием цирроза.

В отличие от HBV, развитие HCV-индуцированного ГЦР происходит только в печени уже пораженной 
циррозом [13]. Риск возникновения ГЦР у пациентов c HCV-индуцированным циррозом в 17 раз выше, чем в здоровой популяции и составляет $1-4 \%$ в год (в японской когорте - до 8\% в год) [7, 13]. Дополнительными факторами, увеличивающими риск ГЦР, являются мужской пол, коинфекции (HBV или HIV), генетическая предрасположенность, пожилой возраст, генотип вирусов Ib и III, длительность инфицирования, наличие ожирения и сахарного диабета, а также употребление алкоголя [7]. Кроме ГЦР HCV может вызывать развитие холангиоцеллюлярного рака, а также В-клеточной неходжкинской лимфомы, лимфомы маргинальной зональной, лимфоплазматической лимфомы и фолликулярной лимфомы [7].

Вакцинации против HCV-инфекции не существует, однако в лечении этого заболевания в последние годы были достигнуты колоссальные успехи. Появление в 2013 году новых противовирусных препаратов прямого действия (direct acting antivirals, DAA), стало крупным прорывом из-за их высокой эффективности и безопасности. Внедрение DAA (Софосбувир, Даклатасвир, Ледипасвир и др.) привело к тому, что на сегодняшний момент почти каждый пациент с хронической HCV-инфекцией может быть вылечен, так как устойчивый вирусологический ответ наблюдается в 90-95\% случаев [7]. Однако, даже успешная DAA-терапия, приведшая к излечению пациента с циррозом, не может полностью устранить риск развития ГЦР в дальнейшем. Этот риск существенно снижается, но все равно остается на уровне $0,33 \%$ в год, поэтому у пациентов с циррозом даже вылечившимся от HCV-инфекции необходимо длительное динамическое наблюдение [7]. Тем не менее, ожидается, что искоренение HCV-инфекции в странах, которым доступна DAA-терапия, будет иметь колоссальное значение для снижения заболеваемости циррозом и ГЦР в следующих десятилетиях.

\section{HDV-индуцированный канцерогенез}

Вирус гепатита дельта является спутниковым одноцепочным РНК-вирусом, который зависит от HBV, необходимого ему для воспроизводства и распространения [13]. Таким образом, HDV может присутствовать в организме человека только в качестве коинфекции. HDV-инфекция не является цитопатической и не оказывает прямого онкогенного воздействия. Однако активация опосредованных воспалительных реакций и окислительного стресса способствуют усилению канцерогенного эффекта HBV [13]. Сочетание HBV-HDV-инфекции которой заражено около 20 миллионов человек приводит к более выраженному воспалению и тяжелому заболеванию печени, чем при моноинфекции HBV [13]. Наличие HDV значительно ускоряет развитие фиброза и цирроза, а также существенно повышает риск развития ГЦР. На долю HBV-HDV приходится почти половина всех случаев ГЦР в высокоэндемичных районах, таких как Турция,
Италия и Монголия [6]. На сегодняшний момент как вакцинации, так и эффективной противовирусной терапии HDV-инфекции не существует.

\section{4. Участие в канцерогенезе нескольких семейств вирусов}

Если риск развития ГЦР у пациентов с HBV- и HCV-инфекцией повышен примерно в 20 и 17 раз, соответственно, то сочетание HBV-HCV-инфекции увеличивает риск возникновения ГЦР уже в 165 раз [6]! Оба вируса могут играть активную роль на различных этапах канцерогенеза, вызывая при этом синергетический эффект. Частота ГЦР также выше среди пациентов с HIV-инфекцией, чем в контрольной группе населения в целом. Кроме того, HIV является дополнительным кофактором, увеличивающим риск развития ГЦР у пациентов с HBV-инфекцией, HCV-инфекцией, HBV-HDV-инфекцией, HBV-HCVинфекцией и HBV-HDV-HCV-инфекцией $[6,7,12,13]$.

\section{IV. ЦИРРОЗ ПЕЧЕНИ И ХИРУРГИЧЕСКОЕ ЛЕЧЕНИЕ ГЦР}

\section{1. Цирроз печени как конкурирующее с ГЦР смертельное заболевание}

Осложнения, связанные с развитием цирроза печени - основная причина гибели пациентов, страдающих хроническими вирусными гепатитами. На сегодняшний момент среди всех причин смерти цирроз занимает 14 место в мире и 4 место в Европе, ежегодно унося жизни более 1 миллиона человек. Все сложности, возникающие при лечении ГЦР, связаны с тем, что подавляющее большинство случаев (более 90\%) заболевания развивается на фоне цирроза. При этом цирроз не является предраковым заболеванием, а представляет параллельный процесс, возникающий в ответ на те же внешние стимулы, что и гепатоканцерогенез. Хроническое воспаление, вызывающее повторяющиеся циклы клеточного повреждения и регенерации гепатоцитов, играет решающую роль в развитии обоих заболеваний. Цирроз гистологически характеризуется появлением узловых регенераций, окруженных плотными фиброзными перегородками. При хроническом вирусном воздействии происходит паренхиматозное вымирание, сопровождающееся микрососудистой трансформацией. Микрососудистые изменения характеризуются синусоидальным ремоделированием, капилляризацией печеночных синусоидов, формированием внутрипеченочных шунтов и эндотелиальной печеночной дисфункцией [14]. Повреждение сосудистого русла приводит к росту периферического сопротивления и, как следствие, - к портальной гипертензии. Именно возникновение портальной гипертензии (доклинической и клинически значимой) и знаменует переход фиброза в цирроз $и$ именно портальная гипертензия играет ключевую роль в развитии всех осложнений, ведущих к смерти 
пащиентов. При развитии клинически значимой портальной гипертензии, проявляющейся асцитом, кровотечениями, энцефалопатией, желтухой или сепсисом, прогноз прогрессивно ухудшается. Поэтому у пациентов с диагностированным ГЦР для определения тактики лечения, прежде всего, необходимо выяснить прогноз по каждому заболеванию в отдельности, так как каждое из них может привести к смерти больного. Более того, можно говорить о том, что у пациентов, страдающих вирус-ассоциированным ГЦР, выраженность цирроза является ключевым фактором для выбора тактики лечения.

\section{2. Цирроз печени: смена парадигмы}

Более полутора веков в медицинском сообществе понятие «цирроз» рассматривалось как единое состояние, характеризующее терминальную стадию хронического заболевания печени (фиброза) с однозначно определенным неблагоприятным прогнозом. Наиболее распространенная система гистологической оценки выраженности фиброза печени METAVIR выделяет пять этапов, среди которых F0 соответствует отсутствию фиброза, F1 - портальному фиброзу, F2 - перипортальному фиброзу, F3 - мостиковому фиброзу и F4 - циррозу. Аналогичным образом системы оценки Ishak и Scheuer также пытаются полуколичественно определить выраженность фиброза. Согласно этим системам, как только фиброз достигает заключительного этапа, устанавливается диагноз цирроза и процесс считается «конечной стадией» с патологической точки зрения [14]. Однако колоссальный прогресс медицины, произошедший в последнее десятилетие и связанный в первую очередь с разработкой эфбективных схем противовирусной терапии, потребовал пересмотра этой концепции [15]. В настоящее время необходимо говорить о циррозе как о динамическом процессе, характеризующем продвинутую (но не терминальную) стадию фиироза и имеющем 1-годичный прогноз летальности от 1\% до $100 \%$. Более того, с внедрением эффективной противовирусной терапии, цирроз начинает рассматриваться как обратимый процесс, требующий своего стадирования, лечения и мониторинга $[14,15]$. В связи с этим предложенные ранее прогностические классификации, такие как Child-Pugh и MELD (Model for End-Stage Liver Disease) перестали в настоящее время удовлетворять потребности клиницистов, занимающихся лечением цирроза [14].

В 2010 году Garcia-Tsao G. et al. была предложена принципиально новая удобная и практичная система стадирования цирроза печени, сочетающая в себе гистологические, клинические, гемодинамические и биологические особенности этого заболевания с возможностью оценки прогноза [15]. Согласно этой системе, цирроз необходимо разделять на компенсированный и декомпенсированный этапы, имеющие различный прогноз и ожидаемую продолжительность жизни. В компенсированном циррозе предложено выделять две стадии в зависимости от наличия или отсутствия варикозно-расширенных вен пищевода. Декомпенсированный цирроз определяется развитием клинических проявлений, таких как асцит, кровотечение, печеночная энцефалопатия и т.д. Важным преимуществом данной классификации является то, что она тесно привязана к морфологическому стадированию и к выраженности портальной гипертензии [15].

Как известно, золотыл стандартом морфологической диагностики фиброза является чрескожная биопсия. Однако в практической работе оценка стадии цирроза с помощью биопсии имеет серьезные недостатки, такие как риск кровотечения и ошибки при заборе материала. Основным ограничением методики является то, что она отражает состояние только 1/50 000 части паренхимы и не дает представления о состоянии органа в целом. Кроме того биопсия плохо подходит для мониторинга динамики цирротических изменений, например при анализе эффективности проводимой терапии [14].

Единственным надежным способом оценки функционального состояния цирротически-измененной печени считается измерение градиента венозного давления печени (hepatic venous pressure gradient, HVPG), являющегося косвенным (суррогатным), отражением давления в воротной вене [16]. Нормальный HVPG составляет 3-5 мм. рт. ст., тогда как градиент равный 10 ми .рт. ст. является пороговым и рассматривается как лучший предиктор развития варикозного расширения вен и клинической декомпенсации. Поэтому HVPG более 10 мм. рт. ст. определяется уже как клинически значимая портальная гипертензия $[15,16]$. Примечательно, что повторные кровотечения из варикозно-расширенных вен пищевода и асцит не возникают при условии снижения HVPG ниже уровня в 12 мм. рт. ст. и, следовательно, этот порог тесно связан с наличием декомпрессирующих событий [15].

Измерение HVPG представляет собой технически простую рентгенохирургическую процедуру, описанную впервые Novak D. et al. в 1977 году. Суть ее заключается в установке баллонного катетера 7F в долевую или сегментарную ветвь печеночной вены яремным или бедренным доступом под рентгенологическим контролем. После прямого измерения свободного давления баллон раздувают до полного прекращения кровотока и измеряют «заклиненное» давление, соответствующее давлению в синусоидах печени. Разница между заклиненным и свободным давлением и составляет HVPG [16]. Установлено, что HVPG не только отражает функциональное состояние печени, но и имеет корреляцию с гистологической стадией фиброза [14-16]. У пациентов с циррозом печени HVPG также предоставляет независимую прогностическую оценку ожидаемой продолжительности жизни и риска декомпенсации. Кроме того, измерение HVPG является информативным показателем для оценки 
эффективности проводимой противовирусной терапии и терапии, направленной на лечение портальной гипертензии. Показано также, что HVPG является независимым предиктором риска развития ГЦР - у пациентов с HVPG более 10 мм. рт. ст. он повышен в 6 раз $[15,16]$. Недостатком процедуры измерения HVPG является ее инвазивность, а также недоступность для тех клиник, где нет рентгенохирургической службы. В связи с этим предпринимались неоднократные попытки поиска неинвазивной альтернативы этой методике. Для этой цели изучались различные лабораторные тесты, эластография, доплерография, CEUS, КТ и МРТ, однако ни один из этих методов не смог заменить измерение HVPG, вплоть до сегодняшнего дня [17]. Поэтому в настоящее время измерение HVPG остается золотыл стандартом оценки гемодинамики и функционального состояния печени при циррозе и должно широко использоваться для определения стадии фиброза, оценки общего прогноза заболевания, мониторинга эффективности противовирусной терапии и терапии портальной гипертензии, а также для стратификации рисков хирургического лечения ГЦР [14-17]. Измерение HVPG должно стать рутинной процедурой во всех медицинских учреждениях, занимающихся диагностикой и лечением рака печени.

3. Стадирование цирроза и прогноз заболевания

В 2015 году классификация Garcia-Tsao G. et al. была усовершенствована Suk K.T. et Kim D.J. с выделением трех дополнительных стадий, характеризующих декомпенсированный этап развития цирроза в зависимости от уровня HVPG (табл. 6) [16]. В соответствии с этой классификацией (клас- сификащия цирроза по Garcia-Tsao G. и Suk K.T.) на стадиях METAVIR F1-F3 (нецирротические стадии хронического заболевания печени) без гистологических и клинических данных за цирроз HVPG находится в пределах нормального диапазона (1-5 Mм. рт. ст.) [16]. Цирротическая стадия (METAVIR F4) подразделяется на два этапа - компенсированный и декомпенсированный. Компенсированный этап, как уже говорилось ранее, имеет две стадии. Первая стадия (компенсированный цирроз без вариксов) наблюдается до формирования варикозно-расширенных вен пищевода при уровне $H V P G$ 6-10 $\mathrm{mm} . \mathrm{pm} . \mathrm{cm}$. и имеет прогноз 1-годичной летальности не более $1 \%$. вторая стадия (колпенсированный цирроз с вариксами) возникает при повышении HVPG до 10-12 мл. pm. cm. и сопровождается $3 \%$ летальностью в течение 1 года. Декомпенсированный этап имеет также три переходящих одна в другую стадии в зависимости от уровня HVPG и соответствующих этому уровню клинических проявлений. Так, третья стадия (деколпенсированный цирроз с асцитом) клинически проявляется асцитом, что соответствует повышению HVPG до 12-16 мn. pm. cm. и имеет прогноз смерти в течение 1 года на уровне 20-30\%. Четвертая стадия (декомпенсированный цирроз с кровотечением) возникает при повышении HVPG до 16-20 мл. pm. cm. и сопровождается $60 \%$ летальностью в течение года. Повышение давления более $20 \mathrm{m \mu .} \mathrm{pm.} \mathrm{cm.} \mathrm{соответ-}$ ствует пятой стадии (декомпенсированный цирроз с инфекционными осложнениями) и имеет $70-100 \%$ летальность в связи с развитием асцит-перитонита, сепсиса или гепаторенального синдрома (табл. 6) [16].

Согласно современным представлениям, вы-

Таблица 6.

Универсальная система стадирования и прогноза фиброза (цирроза) печени на основании морфологических, гемодинамических и клинических проявлений (Garcia-Tsao G. et al. (2010) [15] в модификации Suk K.T.et Kim D.J. (2015) [16])

\begin{tabular}{|c|c|c|c|c|c|c|}
\hline \multirow{3}{*}{$\begin{array}{c}\text { Классифика- } \\
\text { ция }\end{array}$} & \multicolumn{6}{|c|}{ Стадия } \\
\hline & \multirow{2}{*}{$\begin{array}{c}\text { Нецир- } \\
\text { ротиче- } \\
\text { ская }\end{array}$} & \multicolumn{5}{|c|}{ ЦИРРОТИЧЕСКАЯ } \\
\hline & & \multicolumn{2}{|c|}{ КОМПЕНСИРОВАННАЯ } & \multicolumn{3}{|c|}{ ДЕКОМПЕНСИРОВАННАЯ } \\
\hline METAVIR & F0-F3 & $\mathrm{F} 4$ & F4 & F4 & $\mathrm{F} 4$ & $\mathrm{~F} 4$ \\
\hline $\begin{array}{l}\text { HVPG* } \\
\text { (мМ. рт. ст.) }\end{array}$ & $1-6$ & Более 6 & Более 10 & Более 12 & Более 16 & Более 20 \\
\hline $\begin{array}{l}\text { Клиническая } \\
\text { стадия цирроза }\end{array}$ & 0 & 1 & 2 & 3 & 4 & 5 \\
\hline Характеристика & - & $\begin{array}{c}\text { Цирроз без } \\
\text { вариксов }\end{array}$ & $\begin{array}{c}\text { Цирроз } \\
\text { с вариксами }\end{array}$ & $\begin{array}{c}\text { Цирроз } \\
\text { с асцитом }\end{array}$ & $\begin{array}{c}\text { Цирроз } \\
\text { с кровоте- } \\
\text { чением }\end{array}$ & $\begin{array}{c}\text { Цирроз с асцит- } \\
\text { перитонитом, } \\
\text { сепсисом, } \\
\text { желтухой или } \\
\text { гепаторенальным } \\
\text { синдромом }\end{array}$ \\
\hline $\begin{array}{l}\text { Летальность } \\
\text { в течение года }\end{array}$ & $0 \%$ & $1 \%$ & $3 \%$ & $20-30 \%$ & $60 \%$ & $70-100 \%$ \\
\hline
\end{tabular}


полнение резекции печени у пациентов с ГцР на фоне цирроза целесообразно только в случае компенсированного цирроза 1 стадии, то есть когда HVPG не превышает 10 мм. pm. cm. [15-17]. Выполнение резекции печени у больных с HVPG более 10 мм. рт. ст. сопровождается значительно большим риском развития послеоперационной печеночной недостаточности (более 5\%) и высокой летальностью (более 3\%) и в настоящее время не рекомендуется [16]. При HVPG выше 10 мм. рт. ст. необходимо рассматривать возможность трансплантации печени. Она может быть выполнена в том случае, когда пациент соответствует Миланским критериям, то есть у него выявляется один узел $\leq 5$ см или три узла $\leq 3$ см. При этом трансплантация печени является единственным методом лечения, вылечивающим и рак и цирроз, поэтому степень портальной гипертензии для ее проведения значения не имеет. Во всех остальных случаях (HVPG более 10 мм. рт. ст. и/или множественные узлы) применение хирургического лечения считается нецелесообразным. Так как подавляющее число больных ГЦР имеют продвинутые стадии цирроза, а само заболевание диагностируется на более поздних этапах, хирургическому лечению может подлежать очень небольшое число пациентов. Поэтому в качестве альтернативных хирургических технологий все большее распространение приобретают различные минимально-инвазивные вмешательства, относящиеся к области рентгенохирургии (интервенционной радиологии) [16].

\section{V. ВЕДУЩАЯ РОЛЬ ГЦР В РАЗВИТИИ ИНТЕРВЕНЦИОННОЙ ОНКОЛОГИИ}

Острая необходимость поиска эффективных и в то же время безопасных методов лечения вирусассоциированного ГЦР, не поддающегося химиолучевой терапии, возникла уже в 1970-1980-е годы и стала драйвером разработки и внедрения в практику большого числа принципиально новых минимальноинвазивных хирургических вмешательств, выполняемых под рентгенологическим и ультразвуковым контролем. В дальнейшем эти вмешательства стали основой для формирования нового (четвертого) направления клинической онкологии, получившего название интервенщионной онкологии (интервенционной радиологии в онкологии) [18]. В нашей стране эти технологии традиционно относятся к рентгенохирургии.

\section{1. Диагностические вмешательства}

Значительный вклад в развитие не только интервенционной радиологии, но и лучевой диагностики внесли в свое время различные рентгенохирургические (интервенционно-радиологические) методики внутриартериального контрастирования, направленные на выявление ГЦР [19]. Сюда, прежде всего, следует отнести диагностическую ангиографию, впервые применённую для диагностики ГЦР и описанную в 1967 году Үu С. Следующими этапами были внедрение диагностической компьютерно-томографической артериогепатикографии (КТ-АГ), предложенной Prando A. et al. в 1979 году, и КТ-артериопортографии (КТ-АП), описанной Matsui O. et al. в 1983 году. Новые возможности диагностики ГЦР появились с разработкой методики КТ-АГ, направленной на визуализацию зоны перитуморального кольцевого контрастирования ( (corona enhancement») опухолевых узлов диаметром более 10 мм (Inoue E. et al., 1998), а затем с внедрением в практику двухфазной ПДКТ-АГ на ее основе, описанной Miyayama S. et al. в 2011 году [20].

\section{2. Трансартериальная противоопухолевая терапия}

Подавляющее большинство методик трансартериальной терапии опухолей изначально разрабатывалось именно для лечения ГЦР [21]. Так, применение трансартериальной химиоинфузии (ТАХИ) путем чрескожной катетеризации артерий печени для лечения ГЦР впервые описано Massey W.H. et al. в 1971 году. Уже в 1974 году Doyon D. et al. впервые опубликовали опыт выполнения чрескожной трансартериальной эмболизации (ТАЭ) симптомных узлов ГЦР с использованием гемостатической губки. В 1979 году Grady E.D. сообщил о первом клиническом использовании методики селективной внутрипечёночной радиотерапии, основанной на введении в опухолевые сосуды микросфер из резины, насыщенных радиоактивными изотопами Иттрия-90 и получившей впоследствии название трансартериальной радиоэмболизащии (ТАРЭ) [19]. Уже в 1983 году Konno T. et al. предложили методику трансартериальной «химиолипиодолизащии» (ТАХЛ) опухолей печени - химиоинфузии доксорубицина в смеси с масляным контрастным препаратом Липиодолом (Lipiodol Ultra-Fluid, Guerbet, Франция). В том же 1983 году Yamada R. et al. впервые применили методику трансартериальной химиоэмболизации (ТАХЭ) узлов ГЦР с использованием гемостатической губки в смеси с доксорубицином. В 1987 году Takayasu K. et al. описали значительно более эффективный способ ТАХЭ, при котором предложили сначала выполнять ТАХЛ (химиолипиодолизацию) долевой или собственной печеночной артерии, после чего дополнять ее ТАЭ этой же артерии гемостатической губкой [20]. Авторами было убедительно показано, что только ТАХЛ + ТАЭ приводит к выраженному некрозу опухолевых узлов, в то время как ТАХЛ (химиолипиодолизация) или введение липиодола без цитостатика («липиодолизащия») являются практически неэффективными [20]. В дальнейшем предложенная методика получила название Липиодол-ТАХЭ (ЛПТАХЭ). Однако значительное число побочных эффектов и выраженная гепатотоксичность связанные с эмболизацией большого объема печени (вся печень 
или одна из долей) при проведении ЛП-ТАХЭ привели к необходимости дальнейшего научного поиска и разработки более эффективных и одновременно более щадящих методов химиоэмболизации [21]. Так, уже в 1990 году Uchida H. et al. предложили методику сеглентарной (селективной) ТАХЭ (сТАХЭ), а в 1993 году Matsui O. et al. впервые использовали методику субсегментарной (суперселективной) ТАХЭ (ссТАХЭ), направленную на избирательную химиоэмболизацию питающих опухоль артерий с использованием доксорубицина, липиодола и гемостатической губки, вводимых через микрокатетер [21]. Именно эта технология суперселективной (субсегментарной) химиоэмболизащии в дальнейшем получила название классической ТАХЭ (кТАХЭ) и широко используется в настоящее время. Спустя 14 лет, в 2007 году, Miyayama S. et al. была описана усовершенствованная методика кТАХЭ, названная ультраселективной (сверхселективной) ТАХЭ (уТАХЭ) [21]. Для ее осуществления авторы предложили выполнять поочередное «заклинивание» эмболизационного микрокатетера во всех питающих опухоль сосудах, а введение липиодола, доксорубицина и эмболизационного материала осуществлять не «по кровотоку» а под повышенным давлением с заполнением не только опухолевых капилляров, но и ретроградно - перитуморальных синусоидов здоровой паренхимы печени [21]. В 2009 году Irie T. и Takahashi N. дополнительно усовершенствовали методику уТАХЭ, предложив технологию, которую они назвали баллонокклюзионной ТАХЭ (Б-ТАХЭ). Данная технология основана на использовании микрокатетера с микробаллоном в дистальной части, что позволяет полностью отключать опухоль от системного кровотока на момент химиоэмболизации и осуществлять насыщение узла ГЦР и прилежащих к нему перитуморальных синусоидов здоровой паренхимы химиоэмболизатом под очень высоким давлением, что обеспечивает максимальный эффект с высокой надежностью и безопасностью [21].

Параллельно с совершенствованием методик ТАХЭ, основанных на использовании доксорубицина, липиодола и гемостатической губки, шла разработка и других, принципиально новых технологий химиоэмболизации. Так, в 2007 году Varela M. et al. впервые описали новый способ суперселективной ТАХЭ узлов ГЦР с использованием лекарственно-насыщаемых микросфер (ЛНМ), насыщенных доксорубицином (ЛНМ-ТАХЭ). Преимущество методики по сравнению с кТАХЭ заключается в том, что после попадания микросфер в опухоль они начинают медленно высвобождать химиопрепарат в межклеточное пространство, что обеспечивает его постоянную высокую концентрацию в зоне интереса в течение нескольких недель (после кТАХЭ - химиопрепарат определяется в опухоли только в течение нескольких дней) [21]. При этом отмечается почти полное отсутствие проявлений системной токсичности (цитостатик в системный кровоток из микросфер не попадает) и значительное снижение выраженности постэмболизационного синдрома. В настоящее время в связи с доказанной высокой эффективностьюЛНМ-ТАХЭ, наряду скТАХЭ, является стандартом трансартериальной терапии ГЦР. В том же 2007 году Wallace M.J. et al. впервые использовали ПДКТ-АГ для трехмерной навигации во время выполнения химиоэмболизации узлов ГЦР (ПДКТ-контролируемая ТАХЭ). Описанные авторами методики поиска питающих опухоль сосудов и оценки полноты выполнения процедуры в настоящее время также широко применяются и обеспечивают прецизионное и более качественное проведение химиоэмболизации. В 2009 году Kawamura Y. et al. предложили методику ТАХЭ с использованием вместо доксорубицина третьего поколения препаратов платины в виде липофильных комплексов способных растворяться в липиодоле (Мириплатин, Dainippon Sumitomo Pharma, Япония) [21]. Данная технология химиоэлболизащии платиновыми комплексами (ПКТАХЭ) оказалась высокоэффективной во второй линии регионарной терапии ГЦР при отсутствии ответа на лечение после двух кТАХЭ. И наконец, совсем недавно, в 2016 году Chao M. et al. описали методику суперселективной ТАХЭ крупных узлов ГЦР с использованием технологии подавления внутриопухолевого лактоацидоза (ПВЛА-ТАХЭ), направленную на снятие защиты опухолевых клеток от ишемического повреждения путем внутриартериального введения во время кТАХЭ бикарбоната натрия [22]. Использование новой методики ПВЛА-ТАХЭ позволило значительно увеличить число ответов на лечение и общую продолжительность жизни пациентов по сравнению с пациентами, получавшими кТАХЭ [22].

\section{3. Локальная чрескожная терапия}

Одновременно с развитием технологий трансартериальной (регионарной) противоопухолевой терапии шел поиск эффективных минимально-инвазивных методов локальной терапии, способных стать заменой хирургическому лечению у пациентов с небольшими узлами ГЦР на фоне выраженного цирроза. Это привело к появлению химической аблящии $Г Ц Р$, впервые описанной Suqiura N. et al. в 1983 году и получившей название чрескожной инбекционной терапии этанолом (ЧИТЭ). ЧИТЭ стала первой технологией чрескожной (химической) абляции, продемонстрировавшей принципиальную возможность уничтожения опухолей печени in situ без необходимости их последующего хирургического удаления [18]. При этом методика оказалась очень эффективной для лечения узлов ГЦР диаметром менее 20 мм на фоне выраженного цирроза. Однако, существенными ограничениями ЧИТЭ оказались низкая эффективность лечения ГЦР диаметром более 20 мм (в связи с неравномерным распределением спирта в опухоли), а также невозможность лечения опухолей 
в нецирротической печени. Последнее связано с тем, что жесткая, цирротически-измененная печень, хорошо отграничивает распределение спирта в мягкой (относительно печени) опухолевой ткани, позволяя ему постепенно и равномерно инфильтрировать весь объем новообразования, тогда как в нецирротической печени спирт вытекает из опухоли и распределяется в здоровой (более мягкой) паренхиме. Это стало причиной дальнейшего научно-технического поиска приведшего к появлению нового направления локальной терапии - чрескожной энергетической аблящии (ЧЭА), практически лишенной недостатков химической абляции опухолей [23]. Так, уже в том же 1983 году Bown S.G. et al. описали методику чрескожной интерстициальной лазерной абляиии (ЧИЛА) небольших узлов ГЦР [23]. Понадобилось еще 11 лет, чтобы в 1994 году Seki T. et al. сообщили об успешном использовании для лечения ГЦР методики чрескожной микроволновой аблящии (МВА), а чуть позже, в 1995 году, Rossi S. et al. - методики радиочастотной аблящии (РЧА) [23]. В 1998 году вышла первая публикация Schuder G. et al., описавшая методику и результаты лечения опухолей печени методом чрескожной криоаблящии (ЧК). В 2003 году Engelmann K. et al. сообщили об успешном использовании чрескожной интерстициальной фотодинамической аблящии (ЧИФДА) для лечения опухолей печени. В 2011 году Thomson K.R. et al. опубликовали первые данные по клиническому использованию технологии чрескожной необратимой электропоращии (ЧНЭ) [23].

Кроме того, необходимо упомянуть о том, что в 1984 году Makuuchi M. et al. описали методику предоперационной эмболизации ветвей воротной вены (ПЭВВ), вызывающей гипертрофию контралатеральной доли печени для снижения риска печеночной недостаточности у пациентов с циррозом в послеоперационном периоде. В 1989 году Richter G.M. et al. впервые выполнили наложение транспеченочного портосистемного шунта (TIPS) для лечения портальной гипертензии у пациентов с декомпенсированным циррозом, находящихся на листе ожидания трансплантации печени [19]. Эти две минимальноинвазивные рентгенохирургические технологии (TIPS и ПЭВВ) позволили в дальнейшем расширить возможности хирургического лечения пациентов с ГЦР на фоне цирроза печени.

Часть из описанных в данном разделе технологий представляет собой только исторический интерес (например, ТАХЛ и ЧИФДА), другие после тщательных, ранее проведенных исследований, составляют основу современной терапии ГЦР и входят в большинство международных рекомендаций по лечению этого заболевания (например, ЛНМ-ТАХЭ и РЧА), третьи, более новые - находятся в стадии активного клинического изучения (например, ПВЛА-ТАХЭ и ЧК). Более того, значительная часть хорошо зарекомендовавших себя технологий (в первую очередь - технологии
ЧЭА) уже сегодня широко используются в лечении других первичных и метастатических опухолей, таких как рак легкого, почек, надпочечников, костей и т.д. [23]. Таким образом, потребность в минимально-инвазивном лечении ГЦР сыграла ведущую роль в становлении и развитии нового направления клинической онкологии - интервенционной онкологии [18].

\section{VI. РОЛЬ БИОПСИИ В ДИАГНОСТИКЕ ГЦР}

ГЦР является единственной злокачественной опухолью, для которой выполнение биопсии и получение гистологического заключения в настоящее время не является обязательным. Для подтверждения диагноза ГЦР в печени на фоне цирроза достаточно использовать неинвазивные критерии диагностики ГЦР. Эти критерии были разработаны AASLD (American Association for the Study of Liver Diseases) и дополнены LI-RADS (Liver Imaging Reporting and Data System). Суть неинвазивных критериев заключается в том, что при проведении МСКТ или МРТ с внутривенным контрастированием крупные узлы ГЦР в цирротической печени характеризуются выраженным контрастным усилением в артериальную фазу и быстрым «вымыванием» контрастного препарата в портальную фазу [24]. Таким образом, присутствие этих двух признаков считается достаточным для верификации диагноза. Данные критерии стали применяться EASL (European Association for the Study of the Liver) еще до появления таргетной терапии и были направлены на снижение риска массивных кровотечений $(0,5 \%$ после тонкоигольной и $1,1 \%$ после гильотинной биопсии), развития имплантационных метастазов $(1,4-2,7 \%)$ и исключения ложно-отрицательных результатов (чувствительность и специфичность гильотинной биопсии составляют 86-96\% и 95-100\%, соответственно), затягивающих начало лечения [25]. Однако на сегодняшний момент известно, что чем меньшего размера ГЦР мы хотим обнаружить, тем меньше характер его контрастирования будет укладываться в критерии LI-RADS. Связано это с особенностями гепатоканцерогенеза, при котором развитие рака начинается в диспластических узлах с последующим медленным инфильтративным ростом опухоли в пределах этих узлов без явного изменения его васкуляризации [24]. Такие узлы, гистологически классифицируемые как ранний рак или рак in situ, имеют смешанное кровоснабжение до достижения размеров 15-20 мм [24]. Поэтому, как показывает практика, только $30 \%$ узлов ГЦР диаметром 10-20 ми полностью соответствуют диагностическим критериям LI-RADS, а узлы диаметром менее 10 ми имеют вообще иной тип контрастирования [24]. В связи с этим, более чем в $70 \%$ случаев при выявлении узлов диаметром 10-20 мм для их верификации требуется выполнение биопсии даже с учетом действующих рекомендаций. Так как главным условием успешного лечения ГЦР является его раннее выявление, роль биопсии в диагностике данного за- 
болевания будет неуклонно расти.

С другой стороны, около 20\% образований имеющих «типичный» для ГЦР вариант контрастирования и расположенных в цирротической печени могут на самом деле являться холангиоцеллюлярным или гепатохолангиоцеллюлярным раком [25]. В частности, в настоящее время высказаны предположения о том, что низкая эффективность Сорафениба в ряде клинических исследований может быть объяснена именно наличием у пациентов не ГЦР, а холангиокарциномы или смешанной опухоли [25]. В связи с этим все клинические исследования, которые будут проводиться в будущем должны использовать биопсию для дифференциальной диагностики этих первичных опухолей печени. Недавно было показано, что дифференцировка опухоли и степень микрососудистой инвазии сильно коррелируют с выживаемостью пациентов как после резекции, так и после трансплантации печени. Поэтому считается, что перед резекцией и трансплантацией печени биопсия может оказаться полезной, если она в состоянии каким-то образом повлиять на тактику лечения.

Согласно существующим рекомендациям биопсия необходима также во всех случаях, когда ГЦР выявлен в печени без признаков цирроза [25]. Известно, что в печени пораженной циррозом доброкачественные патологические образования (за исключением диспластических узлов) отсутствуют, а метастазирование других опухолей является казуистическим. В то же время при отсутствии цирроза в ней могут обнаруживаться как доброкачественные опухоли (например, гемангиомы, аденомы, фокальная нодулярная гиперплазия и т.д.), так и гиперваскулярные метастазы по характеру кровоснабжения идентичные ГЦР (например, метастазы нейроэндокринных опухолей, меланомы или рака почки). Все они требуют проведения морфологической верификации.

Ну и наконец, необходимо сказать о том, что уже сегодня ГЦР рассматривается как гетерогенная опухоль, имеющая множество гистологических подтипов с различными морфологическими характеристиками. В частности, ранее были описаны такие варианты ГЦР как фиброламеллярный, стеатопатический, цирротический, лимфоэпителиальный, воспалительный и макротрабекуллярный [25]. Проводится большое число исследований призванных определить влияние различных гистологических и молекулярно-генетических подтипов ГЦР на эффективность его лечения. Поэтому, как только все сигнальные пути для каждого подтипа ГЦР будут установлены, биопсия станет необходимой частью обследования, требующегося для выбора оптимальной тактики лечения пациентов [25].

Таким образом, значение биопсии в диагностике ГЦР будет неуклонно расти по мере развития стратегий персонализированной медицины. Внедрение в практику новых визуализационных и навигационных технологий, таких как ПДКТ и электромагнитная на- вигация [26, 27], позволит повысить точность таргетирования и эффективность забора материала даже из узлов диаметром менее 10 мм [28, 29]. При этом очевидно, что выполнение биопсии должно быть прерогативой рентгенохирургических (интервенционно-радиологических) отделений, расположенных в крупных специализированных онкологических центрах и имеющих в своем составе соответствующее оборудование и обученный персонал. Только в этом случае биопсия может стать безопасной и максимально информативной процедурой, необходимой для оптимизации лечения больных ГЦР.

\section{VII. СТАДИРОВАНИЕ ГЦР: ДВА ЗАБОЛЕВАНИЯ В ОДНОМ}

\section{1. Системы стадирования: Запад и Восток}

После постановки диагноза ГЦР оценка прогноза заболевания является критически важным шагом для определения тактики лечения. Практически все пациенты с вирус-индуцированным ГЦР, в отличие от больных другими солидными опухолями, имеют одновременно два опасных для жизни заболевания - рак и цирроз. Это очень сильно усложняет оценку общего прогноза и выбор тактики лечения. Первая прогностическая модель для ГЦР на фоне цирроза была разработана Okuda K. et al. в 1985 году и включала такие факторы прогноза, как размер опухоли (менее или более $50 \%$ от объема всей печени) и показатели, характеризующие функциональное состояние органа (наличие асцита, уровень сывороточного альбумина и билирубина) [30]. Система широко использовалась в 1980-е годы, однако со смещением диагностических возможностей в сторону выявления мелких и очень мелких новообразований она утратила свою актуальность. Традиционная для онкологии система стадирования TNM (AJCC/ UICC) используется в настоящее время ограниченно и только для оценки прогноза пациентов, подвергающихся резекции печени без признаков цирроза [30]. Так как AJCC/UICC не учитывает ни состояние печени, ни состояние пациента, она имеет низкую прогностическую ценность у больных с циррозом, особенно оперированных по поводу ранних опухолей.

Идеальная система промежуточного прогноза должна содержать два массива переменных данных. Во-первых, прогностические переменные, описывающие естественную историю течения обоих заболеваний печени, как рака, так и цирроза. Во-вторых, переменные, полученные в результате анализа эффективности существующих методов лечения с целью обоснования целесообразности использования этих методов для каждой конкретной стадии заболевания [31]. Основные прогностические факторы у пациента с ГЦР должны включать информацию о естественной истории болезни, состоянии опухоли (число и размеры узлов, наличие сосудистой инвазии и внепеченоч- 
ного распространения), функциональном состоянии печени (определяется уровнем билирубина и альбумина, а также степенью портальной гипертензии) и общим состоянием пациента (ECOG). Ранее было предложено семь комплексных систем оценки прогноза ГЦР на фоне цирроза (табл. 7). Три из них (CLIP, GRETCH и BCLC) разработаны Европейскими клиниками, четыре - клиниками, расположенными в Азии
(CUPI, HKLC, JIS и Токийская система) [30]. При этом возникли серьезные разночтения, как в определении факторов прогноза, так и тактики лечения ГЦР в Западных странах и странах Азиатско-тихоокеанского региона (табл. 8) [31, 32]. Связано это с тем, что вирусы, участвующие в канцерогенезе (HBV, HCV, HBV-HDV и т.д.), а также клиническое течение ГЦР сильно различаются в этих регионах. В Европе и США преобладает Системы стадирования ГЦР на фоне цирроза по данным Hansmann J. et Ray C.E. (2017) [30]
в модификации

Таблица 7.

\begin{tabular}{|c|c|c|c|c|c|}
\hline $\begin{array}{c}\text { Система } \\
\text { стадирования }\end{array}$ & Год & $\begin{array}{c}\text { Оценка } \\
\text { функций } \\
\text { печени }\end{array}$ & $\begin{array}{c}\text { Характеристики } \\
\text { опухоли }\end{array}$ & $\begin{array}{c}\text { Общее } \\
\text { состояние } \\
\text { пациента } \\
\text { (ECOG) } \\
\end{array}$ & $\begin{array}{c}\text { Стадии } \\
\text { заболе- } \\
\text { вания }\end{array}$ \\
\hline Okuda K. & 1985 & $\begin{array}{l}\text { Асцит, альбумин, } \\
\text { билирубин }\end{array}$ & $\begin{array}{c}\text { Объем поражения более или } \\
\text { менее } 50 \% \text { печени }\end{array}$ & Нет & I-III \\
\hline CLIP & 1998 & $\begin{array}{c}\text { Класс по Child-Pugh, } \\
\text { АФП }\end{array}$ & $\begin{array}{c}\text { Число узлов, объем } \\
\text { поражения более или менее } \\
\text { 50\%, тромбоз воротной вены }\end{array}$ & Нет & $0-2$ \\
\hline BCLC & 1999 & $\begin{array}{l}\text { Класс по Child-Pugh } \\
\text { (с } 2018 \text { г. - ALBI) }\end{array}$ & $\begin{array}{l}\text { Число узлов, размер узлов, } \\
\text { инвазия в воротную вену, } \\
\text { внепеченочные метастазы }\end{array}$ & Да & $0, \mathrm{~A}-\mathrm{D}$ \\
\hline GRETCH & 1999 & $\begin{array}{c}\text { Билирубин, } \\
\text { щелочная } \\
\text { фосфатаза, АФП } \\
\end{array}$ & Тромбоз воротной вены & Да & $0-3$ \\
\hline CUPI & 2002 & $\begin{array}{c}\text { Асцит, щелочная } \\
\text { фосфатаза, АФП, } \\
\text { билирубин }\end{array}$ & Стадирование по TNM & $\begin{array}{l}\text { Наличие } \\
\text { симптомов }\end{array}$ & $1-3$ \\
\hline JIS & 2003 & Класс по Child-Pugh & $\begin{array}{l}\text { Стадирование по TNM } \\
\text { в модификации LCSGJ }\end{array}$ & Нет & $0-3$ \\
\hline Tokyo & 2005 & $\begin{array}{l}\text { Альбумин, } \\
\text { билирубин }\end{array}$ & Число узлов, размер узлов & Нет & $0-2$ \\
\hline $\begin{array}{l}\text { AJCC/ UICC } \\
\text { TNM }\end{array}$ & 2010 & $\begin{array}{c}\text { Оценка степени } \\
\text { фиброза }\end{array}$ & $\begin{array}{l}\text { Число узлов, размер узлов, } \\
\text { инвазия в воротную вену, } \\
\text { внепеченочные метастазы }\end{array}$ & Нет & $\begin{array}{l}\mathrm{T} 1-\mathrm{T} 4, \\
\mathrm{~N} 0-\mathrm{N} 1, \\
\mathrm{M} 0-\mathrm{M} 1\end{array}$ \\
\hline HKLC & 2014 & Класс по Child-Pugh & $\begin{array}{c}\text { Число узлов, размер узлов, } \\
\text { инвазия в воротную вену, } \\
\text { внепеченочные метастазы }\end{array}$ & Да & $\mathrm{I}-\mathrm{V}$ \\
\hline ALBI & 2015 & $\begin{array}{c}\text { Градиент } \\
\text { альбумин-билирубин }\end{array}$ & Нет & Нет & $1-3$ \\
\hline PALBI & 2015 & $\begin{array}{c}\text { Градиент } \\
\text { тромбоциты- } \\
\text { альбумин-билирубин }\end{array}$ & Нет & Нет & $1-3$ \\
\hline ALBI-JIS & 2016 & ALBI & $\begin{array}{l}\text { Стадирование по TNM } \\
\text { в модификации LCSGJ }\end{array}$ & Нет & $0-3$ \\
\hline ALBI-BCLC & 2016 & ALBI & $\begin{array}{l}\text { Число узлов, размер узлов, } \\
\text { инвазия в воротную вену, } \\
\text { внепеченочные метастазы }\end{array}$ & Да & $0, \mathrm{~A}-\mathrm{D}$ \\
\hline \multicolumn{6}{|c|}{$\begin{array}{l}\text { Сокращения: CLIP - Cancer of the Liver Italian Program; BCLC - Barcelona Clinic Liver Cancer; GRETCH - Groupe d'Etude et } \\
\text { de Traitement du Carcinome Hepatocellulaire; CUPI - Chinese University Prognostic Index; JIS - Japan Integrated Staging Score; } \\
\text { AJCC - American Joint Committee on Cancer; UICC - Union for International Cancer Control; TNM - tumor-node-metastasis; } \\
\text { HKLC - Hong Kong Liver Cancer Staging System; ALBI - albumin-bilirubin gradient; PALBI - platelet-albumin-bilirubin gradient; } \\
\text { LCSGJ - Liver Cancer Study Group of Japan; ECOG - Eastern Cooperative Oncology Group; AФП - альфa-фетопротеин. }\end{array}$} \\
\hline
\end{tabular}


HCV-индуцированный рак на фоне тяжелого цирроза, в то время как в странах Азиатско-тихоокеанского региона подавляющее число случаев ГЦР (за исключением Японии) приходится на HBV-индуцированный рак, возникающий на фоне умеренно выраженного цирроза или без него [31-33]. В целом все системы стадирования были протестированы в клинических условиях и показали результативность их использования, однако, только три из них (CUPI, BCLC и HKLC) содержат все три группы необходимых переменных данных, о которых говорилось выше. При этом только две классификации (BCLC и HKLC) включают в себя рекомендации по тактике лечения пациентов в зависимости от конкретного прогностического подкласса (табл. 8). Так как HKLC создавалась для азиатской когорты пациентов, преимущественно инфицированных HBV, и не тестировалась в европейских условиях, она в настоящее время не может быть рекомендована для использования в России. В связи с этим оптимальной для практической работы можно считать систему BCLC (Barcelona Clinic Liver Cancer), разработанную Llovet J.M., Bru C. et Bruix J. в 1999 году [34].

\section{BCLC как оптимальная система стадирования ГЦР}

BCLC обладает рядом несомненных преимуществ перед другими системами стадирования и прогноза. Включенные в нее алгоритмы лечения были изучены в крупных когортных и рандомизированных исследованиях $[31,34]$. ВCLC широко используется по всему миру и неоднократно протестирована в различных клинических ситуациях, в том числе и в России, где показала свою высокую прогностическую ценность [35]. BCLC дает возможность рестадировать пациентов как в сторону ухудшения прогноза при прогрессировании ГЦР (или цирроза), так и в сторону его улучшения в связи с эффективностью проводимой терапии. Кроме того она является развивающейся системой, позволяющей по мере необходимости внедрять в нее новые методы лечения при получении доказательств их эффективности. Классификация с 1999 года уже несколько раз обновлялась. В 2003 году в нее была добавлена стадия BCLC 0 (очень ранний ГЦР), а также рекомендована к применению методика кТАХЭ для лечения промежуточной стадии заболевания (BCLC B). В 2008 году в

Компоненты, входящие в основные системы стадирования,

Таблица 8. по данным Hansmann J. et Ray C.E. (2017) [30] в модификации

\begin{tabular}{|c|c|c|c|c|c|c|c|c|c|c|c|}
\hline \multicolumn{12}{|c|}{ Системы стадирования } \\
\hline Компоненты оценки & $\frac{y}{\frac{\pi}{E}}$ & 哥 & 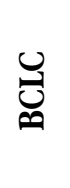 & 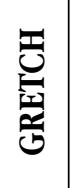 & $\overline{\underline{S}}$ & $\stackrel{\varrho}{=}$ & $\frac{8}{0}$ & 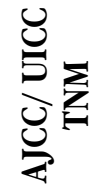 & & 党 & $\overrightarrow{\underline{\theta}}$ \\
\hline \multicolumn{12}{|c|}{ Состояние печени } \\
\hline Асцит & $\mathrm{X}$ & & & & $\mathrm{X}$ & & & & & & \\
\hline Альбумин & $\mathrm{X}$ & & & & & & $\mathrm{X}$ & & & $\mathrm{X}$ & $\mathrm{X}$ \\
\hline Щелочная фосфатаза & & & & $\mathrm{X}$ & $\mathrm{X}$ & & & & & & \\
\hline Альфа-фетопротеин & & $\mathrm{X}$ & & $\mathrm{X}$ & $\mathrm{X}$ & & & & & & \\
\hline Child-Pugh & & $\mathrm{X}$ & $\mathrm{X}^{*}$ & & & $\mathrm{X}$ & & & $\mathrm{X}$ & & \\
\hline Инвазия в воротную вену & & $\mathrm{X}$ & $\mathrm{X}$ & $\mathrm{X}$ & & & & $\mathrm{X}$ & $\mathrm{X}$ & & \\
\hline Число тромбоцитов & & & & & & & & & & & $\mathrm{X}$ \\
\hline Общий билирубин & $\mathrm{X}$ & & & $\mathrm{X}$ & $\mathrm{X}$ & & $\mathrm{X}$ & & & $\mathrm{X}$ & $\mathrm{X}$ \\
\hline \multicolumn{12}{|c|}{ Состояние опухоли } \\
\hline Метастазы & & & $\mathrm{X}$ & & & & & $\mathrm{X}$ & $\mathrm{X}$ & & \\
\hline Число узлов & & $\mathrm{X}$ & $\mathrm{X}$ & & & & $\mathrm{X}$ & $\mathrm{X}$ & $\mathrm{X}$ & & \\
\hline Стадия по TNM & & & & & $\mathrm{X}$ & $\mathrm{X}$ & & $\mathrm{X}$ & & & \\
\hline Размер узлов & $\mathrm{X}$ & $\mathrm{X}$ & $\mathrm{X}$ & & & & $\mathrm{X}$ & $\mathrm{X}$ & $\mathrm{X}$ & & \\
\hline \multicolumn{12}{|c|}{ Состояние пациента } \\
\hline Симптомы/ Общее состояние & & & $\mathrm{X}$ & $\mathrm{X}$ & $\mathrm{X}$ & & & & $\mathrm{X}$ & & \\
\hline Рекомендации по лечению & & & $\mathbf{X}$ & & & & & & $\mathbf{X}$ & & \\
\hline $\begin{array}{l}\text { Сокращения: CLIP - Cancer of the } \\
\text { de Traitement du Carcinome Hepato } \\
\text { AJCC - American Joint Committee o } \\
\text { HKLC - Hong Kong Liver Cancer Stag } \\
\text { ” В обновленном варианте } 2018 \text { гс }\end{array}$ & $\begin{array}{l}\text { an Prc } \\
\text { CUPI } \\
\text { UICC } \\
n ; A L B\end{array}$ & $\mathrm{~m}$ & $\begin{array}{l}\mathrm{C}-\mathrm{B} \\
\text { Unive } \\
\text { r Inte } \\
\text {--bili }\end{array}$ & $\begin{array}{l}\text { rcelo } \\
\text { sity } \mathrm{Pr} \\
\text { anatio } \\
\text { abin g }\end{array}$ & & $\begin{array}{l}\text { hic Liv } \\
\text { tic In } \\
\text { incer }\end{array}$ & $\begin{array}{l}\text { er Can } \\
\text { ex; JIs } \\
\text { contrc }\end{array}$ & $\begin{array}{l}\text { GRETC } \\
\text { apan In } \\
\text { NM - tu } \\
\text { let-albu }\end{array}$ & $\begin{array}{l}\text { Group } \\
\text { ated St } \\
\text {-node }\end{array}$ & & $\begin{array}{l}\text { de et } \\
\text { core; } \\
\text { tasis; } \\
\text { ient. }\end{array}$ \\
\hline
\end{tabular}


нее был включен Сорафениб в качестве первой линии терапии опухолей стадии BCLC C. В 2012 году чрескожная абляция была добавлена как курабельный метод терапии пациентов с очень ранним раком (BCLC 0). И наконец, уже в 2018 года в BCLC введены новые лекарственные препараты (Ленватиниб в первой линии терапии и Регорафениб во второй линии) для лечения больных стадии BCLC C. Однако, основным изменением, произошедшим в BCLC 2018 стало исключение из нее двух систем, использовавшихся ранее для оценки функционального состояния печени - Child-Pugh и MELD. Связано это с тем, что Child-Pugh показала недостаточную прогностическую ценность при анализе декомпенсированных стадий цирроза. В частности в ней нет адекватной интерпретации таких событий, как почечная недостаточность, спонтанный бактериальный перитонит и энцефалопатия. Кроме того система Child-Pugh включает в себя некоторые субъективные переменные (например, «минимальный» асцит, определяемый только при УЗИ или энцефалопатию), что также ухудшает ее прогностическую значимость при оценке функционального состояния печени. Вместо параметров Child-Pugh теперь рекомендуется использовать систему ALBI (соотношение альбумина и билирубина), которая, как было показано ранее, позволяет более четко стратифицировать пациентов [34]. B BCLC 2018 в отдельную группу выделены пациенты с «сохраненной функцией печени», которая определяется как «ChildPugbА безлюбых проявлений асцита соответствует 1 и 2 стадиям цирроза (компенсированной без вариксов и компенсированной с вариксами) по классификации Garcia-Tsao G. и Suk K.T. [15, 16]. Кроме того, в обновленной версии BCLC четко прописана «конечная (end-stage) стадия нарушения функции печени» которая аналогична «Child-Pugh C или более ранней стадии, но с плохим прогнозом». По всей видимости, это соответствует 5 стадии цирроза по классификации Garcia-Tsao G. и Suk K.T. и пациенты с таким состоянием печени автоматически попадают в терминальную стадию заболевания (BCLC D). Таким образом, в новой классификации BCLC теперь четко прописан статус трех стадий цирроза - 1, 2 и 5. Тактика лечения и прогноз при 3 и 4 стадиях цирроза (декомпенсированный с асцитом и декомпенсированный с кровотечением), пока остаются не до конца понятными. По всей видимости, это будет являться предметом дальнейших исследований [31,34]. B системy BCLC в настоящее время не входит несколько параметров, которые, теоретически, также могут играть определенную дополнительную роль при оценке прогноза заболевания. К ним относятся, гистологический тип опухоли и ее молекулярно-генетический профиль, наличие или отсутствие эстрагеновых рецепторов, этиология заболевания (HBV, HCV, HBV-HDV), генетическая предрасположенность и др. Все это также может быть интегрировано в BCLC при получении дополнительных сведений о высокой прогностической значимости этих переменных.

\section{BCLC 2018: СТАДИИ, ПРОГНОЗ, ЛЕЧЕНИЕ}

Обновленная в 2018 году стратегия стадирования и лечения ГЦР на фоне цирроза BCLC 2018 с некоторыми нашими комментариями представлена на рис. 4. В классификации BCLC все пациенты с ГЦР на фоне цирроза распределяются по пяти стадиям $(0, \mathrm{~A}$, $\mathrm{B}, \mathrm{C}$ и D) в соответствии с заранее установленными прогностическими переменными и возможными вариантами терапии. В классификацию, как уже было отмечено, интегрированы три вида прогностических факторов: 1) связанные с характеристиками опухоли (размер узлов, число узлов, сосудистая инвазия и наличие внепеченочных метастазов); 2) связанные с функциональным состоянием печени (билирубин, выраженность портальной гипертензии и сохранность функций печени); 3) связанные с состоянием здоровья пациента, обусловленным наличием или отсутствием симптомов ГЦР (ECOG) [31].

\section{1. Очень ранний ГЦР}

(очень ранняя стадия, BCLC 0) [31, 34]

Очень ранний ГЦР представляет собой солитарную опухоль диаметром менее 2 см, без признаков сосудистой инвазии и сателлитных метастазов, которая локализуется в функционально-полноценной печени («Child-Pugh A без асцита», что соответствует 1 и 2 стадии цирроза по классификации Garcia-Tsao G. и Suk K.T.) у пациентов без симптомов заболевания (ECOG 0). Как показывает практика, большинство узлов ГЦР диаметром до 2 см не имеют признаков инвазивного роста и могут быть охарактеризованы как карциномa in situ. Пятилетняя выживаемость в этой группе больных после резекции печени составляет 80-90\%. Аналогичные результаты лечения достигаются и при выполнении РЧА. Систематический обзор и метаанализ, включающий 17 исследований (3996 пациентов после резекции печени и 4424 пациента после РЧА) показал, что проведение РЧА сопровождается аналогичной с резекцией продолжительностью жизни, но имеет существенное преимущество перед последней в виде снижения стоимости лечения. Однако в ряде случаев опухоли диаметром менее 20 мм могут иметь инвазивный рост, проявляющийся микроинвазией в систему воротной вены (25\%) и/или появлением сателлитных микрометастазов вокруг основного узла (10\%), что ухудшает прогноз заболевания. Поэтому преимуществом (единственным) резекции печени перед РЧА является возможность гистологической оценки степени дифференцировки опухоли, микрососудистой инвазии и наличия сателлитных микрометастазов для оценки риска раннего рецидива. Однако, это преимущество может быть реализовано только у пациентов, которым в случае выявленного после резекции высокого риска рецидива может быть в ближайшее время выполнена трансплантация печени. Но 


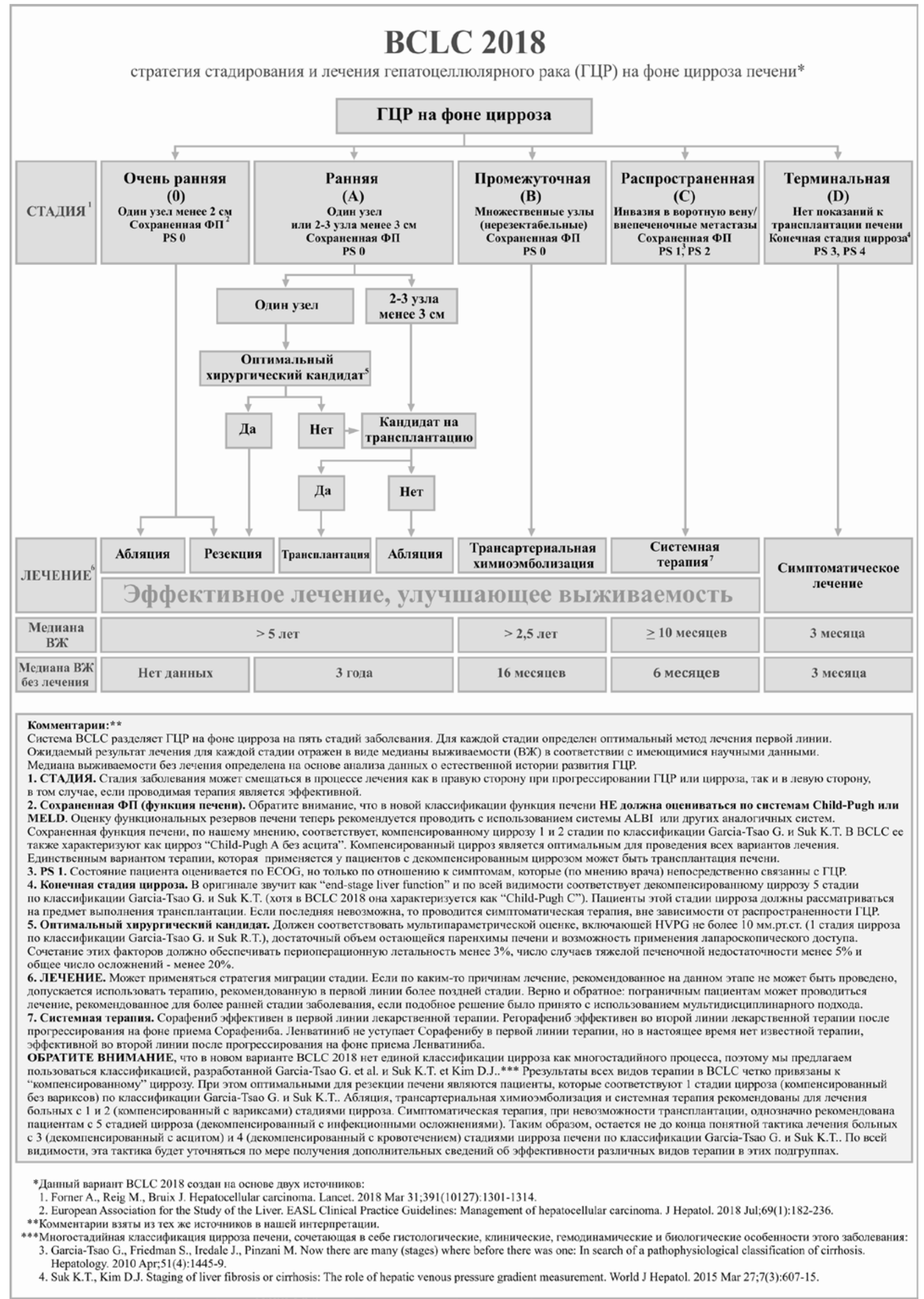

Рис. 4. Стратегия стадирования и лечения ГЦР на фоне цирроза ВСLC 2018 с дополнениями и комлентариями 
если пациент не является кандидатом на трансплантацию, полученные морфологические данные никак не влияют на изменение стратегии его лечения. Поэтому практически у всех больных РЧА (и другие методы ЧЭА) является первой линией терапии ГЦР стадии BCLC 0. Выполнение резекции при этом оправдано только при невозможности осуществления РЧА (например, при прилежании узла к ободочной кишке) или в случае ее технической неэффективности.

\section{2. Ранний ГЦР (ранняя стадия, BCLC A) [31, 34]}

Ранний ГЦР характеризуется наличием одной опухоли диаметром более 2 см или трех опухолей диаметром менее 3 см в печени с сохраненной функцией (1-2 стадия цирроза по классификации GarciaTsao G. и Suk K.T.) у пациентов, не имеющих симптомов заболевания (ECOG 0). Пятилетняя выживаемость больных после трансплантации, резекции или РЧА достигает 50-70\% в тщательно отобранных группах больных. Для солитарных опухолей диаметром более 5 см (без признаков сосудистой инвазии и сателлитных микрометастазов) оптимальным методом лечения является резекция печени. Единичные узлы большого размера характерны главным образом для HBV-индуцированного ГЦР (ориентальный или восточный тип ГЦР) и имеют более благоприятный прогноз. Однако основным условием успешного выполнения резекции является сохраненная функция печени, соответствующая 1 стадии цирроза по классификации Garcia-Tsao G. и Suk K.T. При этом ключевыми предикторами выживаемости больных с солитарной опухолью после резекции являются HVPG $\leq 10$ мм. рт. ст. и нормальный уровень билирубина. Таким образом, на наш взгляд, оптимальные показания крезекиии печени при ГЦР можно сформулировать как 1 (1), то есть 1 узел ГЦР при циррозе 1 стадии. У пациентов с HVPG более 10 мм. рт. ст. в качестве варианта терапии должна рассматриваться трансплантация печени, поскольку она потенциально может вылечить как опухоль, так и цирроз. Однако Миланские критерии строго ограничивают число и размер метастазов (одиночный узел $\leq 5 \mathrm{~cm}$ или три узла $\leq 3 \mathrm{~cm})$ не позволяя оперировать больных с солитарным ГЦР диаметром более 5 см. Таким образом, в подавляющем больиинстве случаев (то есть при наличии нескольких узлов и/или HVPG более 10мл. pm. cm.) для лечения ГЦР стадии BCLC А в качестве первой линии терапии должна использоваться РЧА (и другие методы ЧЭА). Основными предикторами эффективности РЧА являются размеры образования и выраженность цирроза (1 или 2 стадия по классификации Garcia-Tsao G. и Suk K.T.).

\section{3. Промежуточный ГЦР (промежуточная стадия,} BCLC B) [31, 34]

К этой стадии относятся все случаи больших и/или мультифокальных (многоузловых) бессимптомных опухолей без сосудистой инвазии и внепеченочного распространения на фоне сохраненной функции печени. Медиана выживаемости пациентов без лечения в этой группе составляет 16 мес. или 49\% в течение 2 лет. Методом первой линии терапии является ТАХЭ, эффективность которой была подтверждена в двух рандомизированных исследованиях. Как показали недавние когортные исследования, медиана выживаемости больных, при проведении суперселективной (субсегментарной) ТАХЭ (ссТАХЭ) в хорошо отобранных группах пациентов может достигать 40 мес., то есть увеличиваться в 2,5 раза по сравнению с нелеченными пациентами. В настоящее время допускается выполнять кТАХЭ не только у пациентов c Child-Pugh A, но и Child-Pugh B7 (общее число баллов не более 7). Так как когорта больных стадии BCLC B очень разнородна, в дальнейшем, возможно, потребуется ее дополнительная стратификация на подгруппы в зависимости от опухолевой нагрузки и функционального состояния печени.

\section{4. Распространенный ГЦР (распространенная} стадия, ВCLC C) [31, 34]

К этой стадии относятся пациенты с сохраненной функцией печени, но, либо имеющие внепеченочное распространение опухоли (включая поражение регионарных лимфоузлов), либо прорастание опухоли в крупные ветви воротной вены, либо наличие симптомов заболевания, соответствующих ECOG 1-2, а также сочетание этих факторов. Без лечения медиана выживания составляет не более 6-8 мес., или 25\% в год, однако продолжительность жизни в значительной степени зависит от функционального состояния печени и других переменных. Этой группе пациентов рекомендуется лекарственная терапия. При этом Сорафениб показал свою эффективность в первой линии терапии, а Регорафениб оказался эффективным во второй линии терапии после прогрессирования на фоне приема Сорафениба. Ленватиниб не уступает Сорафенибу в первой линии терапии, но в настоящее время нет известной терапии, эффективной во второй линии после прогрессирования на фоне приема Ленватиниба.

\section{5. Терминальная стадия ГЦР (BCLC D) [31, 34]}

К ней относятся пациенты с выраженными симптомами ГЦР, приводящими к инвалидизации (ECOG 3-4), а также все больные с декомпенсированным циррозом конечной 5 стадии (или Child-Pugh C) которым не может быть выполнена трансплантация печени. Медиана выживаемости в этой группе больных составляет 3-4 мес., или 11\% в течение года. Пациентам терминальной стадии ГЦР проводится поддерживающая и симптоматическая терапия.

\section{IХ. РЕЗЕКЦИЯ ПЕЧЕНИ В ЛЕЧЕНИИ ГЦР $[31,34]$}

\section{1. Общие положения}


Резекция печени (наряду с трансплантацией) является наиболее эффективным методом терапии раннего ГЦР (BCLC A) в хорошо отобранных группах пациентов. В этих случаях пятилетняя выживаемость достигает 60-80\%. Большинство проведенных исследований ограничивает показания для резекции печени одной опухолью, поскольку мультифокальность связана с более высокой частотой рецидивов и худшей выживаемостью. В тех случаях, когда множественные узлы технически могут быть удалены, необходимо сравнивать эффективность резекции с результатами других видов лечения, таких как трансплантация, ЧЭА или ТАХЭ. При определении оптимального метода терапии в каждом конкретном случае необходимо стремиться к тому, чтобы максимально увеличить выживаемость с одновременным сохранением высокого качества жизни. Например, резекция печени может рассматриваться как возможный вариант лечения множественных узлов ГЦР, соответствующих Миланским критериям, в том случае, когда невозможно (по различным причинам) выполнить абляцию этих узлов или трансплантацию печени.

Размер опухоли также не является жестко ограничивающим фактором, однако риск микрососудистой инвазии и сателлитного метастазирования возрастает по мере увеличения диаметра новообразования. В связи с этим солитарные опухоли диаметром более 5 см имеют значительно худший прогноз, чем опухоли диаметром менее 5 см и ряд авторов предлагает выделять их в промежуточную подгруппу BCLC A-B.

Известно, что прорастание опухоли в систему воротной вены имеет очень неблагоприятный прогноз, независимо от используемого метода лечения. При этом, в связи с улучшением возможностей лучевой диагностики, частота выявления сосудистой инвазии в последнее время значительно возросла. С одной стороны, это объясняет улучшение результатов резекции печени по сравнению с более ранними исследованиями, но с другой - ограничивает число пациентов, которые могут быть подвергнуты потенциально-курабельной терапии. Поэтому было предложено разделять опухолевые тромбы на четыре вида в зависимости от уровня инвазии воротной вены (PV): PV4 - прорастание в ствол или контралатеральную ветвь воротной вены; PV3 - прорастание в долевую ветвь; PV2 - прорастание в субсегментарную ветвь (ветвь второго порядка) и PV1 - прорастание в сегментарную ветвь. В настоящее время выполнение резекции печени у пациентов с инвазией опухоли PV1/2 считается оправданным только в рамках проведения проспективных научных исследований. Прорастание же на уровне PV3/4 является абсолютным противопоказанием для оперативного вмешательства.

При принятии решения о возможности выполнения резекции печени, а также об объеме операции, ключевую роль играет наличие или отсутствие цир- роза. От выраженности цирроза напрямую зависит функциональное состояние печени, которое необходимо обязательно учитывать. Основным методом предоперационной оценки функционального состояния печени в Восточных странах (в первую очередь в Японии) является анализ скорости элиминации Индоцианина зеленого - флуоресцентного красителя, выводящегося из организма с желчью. В Европейских странах и США золотым стандартом оценки функционального состояние печени служит измерение HVPG и уровня билирубина в сыворотке. Дополнительным (но не самостоятельным) критерием может считаться также число тромбоцитов в крови.

\section{2. Резекция печени у пациентов без цирроза}

Резекция печени - основной вид лечения больных с ГЦР без цирроза. У этих больных с успехом могут выполняться как стандартные, так и расширенные операции с приемлемым числом послеоперационных осложнений. В странах Азиатско-тихоокеанского региона число таких больных может доходить до 40\%, а выбору хирургического метода лечения дополнительно способствует более молодой возраст азиатской когорты пациентов. В то же время, в европейских странах число случаев ГЦР без цирроза не превышает 5\%, при этом большинство заболевших находится в пожилом и старческом возрасте и часто имеет выраженную сопутствующую патологию.

\section{3. Резекция печени у пациентов с циррозом}

Клинически значимая портальная гипертензия (HVPG >10 мм. рт. ст.) в три раза увеличивает вероятность послеоперационной печеночной декомпенсации и в два раза риск смерти в течение 5 лет после резекции печени, по сравнению с пациентами, у которых градиент давления не превышает 10 мм. рт. ст. Поэтому критерии EASL 2018, определяющие показания к резекции печени у пациентов с циррозом, остаются неизменными с 2012 года и их можно сформулировать следующим образом. Идеальным кандидатом для резекции печени на фоне цирроза является пациент с солитарным образованием и очень хорошо сохранившейся функцией органа, что соответствует HVPG $\leq 10$ мм. рт. ст., нормальному уровню билирубина и числу тромбоцитов $\geq 100000 /$ мл. Эти показания должны являться определяющими для большинства медицинских учреждений, имеющих небольшой опыт выполнения подобных вмешательств. Исключение составляют крупные и очень хорошо оснащенные медицинские центры, специализирующиеся на лечении опухолей печени. В них допускается использование «расширенных критериев», консенсус по которым, однако, в рамках рекомендаций EASL 2018, достигнут не был. В любом случае, расширенные показания к резекции печени при циррозе должны выставляться на основе мультипараметрической комплексной оценки функции печени, выраженности портальной 
гипертензии, объема планируемой операции, объема остающейся печени, статуса пациента по ECOG, а также сопутствующих заболеваний. Предоперационные стратегии, направленные на увеличение остающегося после резекции объема печени, являются эффективными и должны применяться для снижения риска развития печеночной недостаточности в послеоперационном периоде [36]. Как показал недавний систематический обзор, среди всех методик, предложенных для индукции гипертрофии контралатеральной доли, максимальный риск серьезных осложнений имеют двухэтапная сплит-ливер резекция печени и ТАРЭ. Более безопасными технологиями являются перевязка воротной вены, ПЭВВ и ТАХЭ+ПЭВВ. При этом сочетание ТАХЭ+ПЭВВ вызывает максимальную гипертрофию печеночной паренхимы в связи с чем считается оптимальной для практического использования [36]. Необходимым условием применения «расширенных критериев» резекции является обеспечение послеоперационной летальности на уровне менее $3 \%$, случаев тяжелой печеночной недостаточности менее $5 \%$ и общего числа послеоперационных осложнений - менее $20 \%$.

\section{4. Неоадъювантная и адъювантная терапия}

К сожалению, рецидив заболевания после перенесенной резекции печени в течение первых 5 лет развивается у $70 \%$ больных. При этом рецидив может быть как истинным (чаще выявляется в первые 2 года после операции), так и являться результатом метахронного канцерогенеза, сопровождающегося появлением опухоли de novo (диагностируется в более поздние сроки). В связи с высоким риском рецидива пациентам рекомендуется длительное наблюдение, причем в первый год интервалы осмотров не должны превышать 3-4 мес. Несколько различных стратегий профилактики ранних и поздних рецидивов были испытаны в различных рандомизированных и когортных исследованиях. Была изучена потенциальная эффективность системной химиотерапии, ТАХЭ и ТАРЭ, а также таргетной терапии Сорафенибом в адъювантном режиме, однако ни один из этих видов лечения не показал никаких положительных результатов. Аналогичная ситуация наблюдается и с применением противовирусной терапии интерферонами и DAA-терапии, которые также не уменьшают риск развития рецидива. Определенные обнадеживающие результаты ранее были получены при использовании ретиноидов, витамина К2 и радиоэмболизации с использованием ${ }^{131}$ І-липиодола, однако эти данные не были полностью подтверждены дальнейшими исследованиями. Таким образом, принимая во внимание имеющуюся информацию, можно говорить о том, что на сегодняшний день не существует эффективных методов адъювантной и неоадъювантной терапии после резекции (и абляции) ГЦР, а само ее проведение является нецелесообразным.
Единственным методом, значительно снижающим риск послеоперационного внутрипечёночного метастазирования (при выявлении микрососудистой инвазии или сателлитных микрометастазов в резецированном препарате), является трансплантация печени, которая должна быть выполнена как можно раньше после резекции, до обнаружения рецидива. Эта стратегия, получившая название ab initio, позволяет максимально эффективно использовать хирургические методы лечения (резекцию и трансплантацию) для терапии ГЦР и в то же время значительно сократить число необходимых донорских органов.

\section{Х. ТРАНСПЛАНТАЦИЯ ПЕЧЕНИ В ЛЕЧЕНИИ ГЦР $[31,34]$}

\section{1. Миланские критерии как эталон отбора} больных

Трансплантация печени представляется лучшим методом лечения ГЦР на фоне цирроза, поскольку позволяет избавить пациента как от опухоли, так и от цирроза. Поэтому в настоящее время трансплантация рекомендуется как вариант первой линии терапии у пациентов, соответствующих Миланским критериям, но не подходящих для выполнения резекции в связи с наличием более чем одной опухоли или клинически значимой портальной гипертензии. Миланские критерии (солитарный узел $\leq 5 \mathrm{~cm}$, или до трех узлов $\leq 3 \mathrm{cm)} \mathrm{являются} \mathrm{эталоном} \mathrm{для} \mathrm{отбора} \mathrm{больных} \mathrm{в}$ Европе и США, обеспечивающим пятилетнюю выживаемость на уровне 65-80\% с числом рецидивов заболевания не превышающим 10-15\%. Все попытки расширения Миланских критериев сопровождаются ожидаемым ростом числа рецидивов и снижением выживаемости в связи с увеличением случаев сосудистой микроинвазии и сателлитного метастазирования. Как было показано недавно, уровень альфа-фетопротеина и вычисление общего объема опухоли имеют важную прогностическую ценность как внутри, так и за пределами Миланских критериев.

Прорастание опухоли в систему воротной вены на любом уровне (PV1-PV4), а также инвазия в любую из печеночных вен являются абсолютными противопоказаниями к трансплантации, поскольку служат самыми важными и независимыми факторами риска для посттрансплантационного рецидива ГЦР, значительно снижающего выживаемость. Однако в случае опухолевой инвазии PV1/2, которая полностью или частично регрессировала на фоне локорегионарной терапии, допускается проведение трансплантации, но только в рамках проспективных научных исследований.

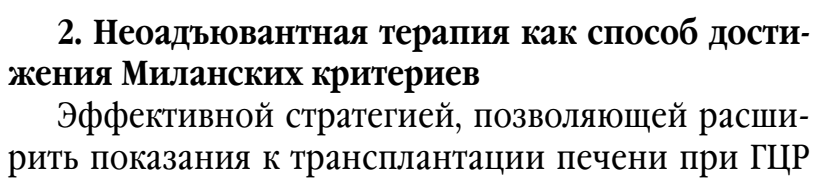


без отказа от Миланских критериев, является применение неоадъювантной локорегионарной терапии. В этом случае пациентам стадии BCLC B, заведомо превышающим Миланские критерии, проводится локорегионарная терапия (ЧЭА, ТАХЭ или их сочетание), позволяющая уменьшить число и/или размеры опухолевых узлов до стадии BCLC A. Интересно, что ответ на проводимую локорегионарную терапию часто связан с наличием гистологических маркеров хорошего прогноза заболевания в виде отсутствия микрососудистой инвазии и сателлитных узлов, а также с высокой дифференцировкой опухоли. Ответ на адъювантную терапию играет важную роль в оценке агрессивности ГЦР и представляет собой инструмент выбора при определении права на пересадку и уточнение ее приоритетности у пациентов с различными показателями. Существует два варианта критериев отбора пациентов в программу неоадъювантного лечения. Первый включает один узел $>5$, но $\leq 6$ см, или 2 узла $\leq 5$ см (с общим диаметром $\leq 8 \mathrm{~cm})$, или $4-5$ узлов $\leq 4 \mathrm{~cm}$ (с общим диаметром $\leq 12 \mathrm{~cm}$ ) при уровне альфа-фетопротеина менее 400 нг/мл. Второй вариант допускает наличие одного узла $\leq 8 \mathrm{~cm}$, или $2-3$ узлов $\leq 5$ см (с общим диаметром $\leq 8 \mathrm{~cm})$, или $4-5$ узлов $\leq 3 \mathrm{~cm}$ (с общим диаметром $\leq 8 \mathrm{~cm}$ ) при уровне альфа-фетопротеина менее 1000 нг/мл. Процент отсева пациентов при проведении неоадъювантной локорегионарной терапии с использованием первого и второго вариантов отбора не превышает 10\% и 35\%, соответственно, в связи с чем оба они могут быть рекомендованы для использования в практической работе.

\section{3. Проблемы нехватки органов и ожидание трансплантации}

Основным ограничением трансплантации печени является нехватка донорских органов, оптимальным источником которых служит трупная печень, полученная от людей с констатированной смертью мозга. Нехватка донорских органов привела к необходимости поиска дополнительных источников «маргинальных» графтов. В результате были сформированы так называемые «расширенные критерии», позволяющие использовать для трансплантации печени при ГцР следующие варианты донорской печени: 1) правая доля печени от живого донора; 2) расщепленная трупная печень, используемая для двух реципиентов; 3) печень, пораженная тяжелым стеатозом; 4) печень, полученная от людей умерших в результате остановки кровообращения. Сегодня около $60 \%$ трансплантаций печени, выполняемых в Европе, осуществляется с использованием маргинальных графтов, однако, даже это не может полностью решить проблему нехватки органов. Связано это с тем, что ГЦР на фоне цирроза является самым быстрорастущим показанием для выполнения трансплантации печени, а пациенты, страдающие ГЦР, составляют около 35\% больных находящихся на листе ожидания.
Постоянная нехватка органов приводит к вынужденному длительному нахождению больных на листе ожидания, во время которого неизбежно происходит прогрессирование заболевания, приводящее к выходу за пределы Миланских критериев. В связи с этим у пациентов, находящихся на листе ожидания более 6 мес., целесообразно проведение неоадъювантной локорегионарной терапии, призванной задержать прогрессирование (стратегия создания «моста к трансплантации»). Несколько исследований и мета-анализов продемонстрировали значительные преимущества такой терапии в снижении риска выбывания пациентов из листа ожидания в связи с прогрессированием. Протоколы этой терапии очень гетерогенны, но во всех центрах суть их сводится к иерархическому использованию ЧЭА и ТАХЭ в различных комбинациях.

\section{XI. ЧРЕСКОЖНЯ АБЛЯЦИЯ В ЛЕЧЕНИИ ГЦР $[31,34]$}

\section{1. РЧА и другие виды чрескожной абляции}

Чрескожная абляция является широко распространенным методом лечения пациентов с ранним и очень ранним ГЦР (BCLC 0, BCLC A).

Практически все проведенные рандомизированные исследования показали более низкую эффективность химической абляции (ЧИТЭ) по сравнению с РЧА, в связи с чем применение ЧИТЭ (как и терапии уксусной кислотой) в настоящее время очень ограничено. Как правило, ЧИТЭ используют либо в случаях невозможности выполнения РЧА для лечения узлов диаметром менее 20 мм (например, при прилежании опухоли к желчному пузырю) либо в сочетании с последней, для повышения эффекта энергетического воздействия [37]. Основными методиками чрескожной абляции являются методики ЧЭА. На сегодняшний момент известно 7 видов ЧЭА, три из которых (РЧА, МВА и ЧК) давно получили всеобщее признание, три находятся на стадии изучения клинической эффективности (ЧИЛА, ЧИФДА и ЧНЭ) и одна (интерстициальная ультразвуковая абляция) проходит этап технических испытаний. Преимущества и недостатки использования различных видов энергий при проведении ЧЭА опухолей были рассмотрены нами ранее в другой работе [23]. Здесь же, вкратце, необходимо сказать только о том, что РЧА стала первым методом энергетического воздействия, получившим широкое распространение в клинической практике из-за низкой стоимости и простоты использования. Однако данная методика имеет ряд принципиальных технологических ограничений, которые не могут быть преодолены в будущем. Основным недостатком РЧА является относительно неболышая зона генерируемого некроза (4-6 см), не позволяющая эффективно лечить опухоли диаметром более 3 см. Вторым недостатком считается высокая зависимость метода от 
әффекта теплопотери, не позволяющего проводить радикальное уничтожение опухолей, прилежащих к сосудам диаметром более 3 мм, в связи с чем существует крайне высокий риск рецидива заболевания. В то же время, такие методы энергетического воздействия как МВА и ЧК в значительной степени лишены этих недостатков, что делает их применение в будущем более перспективным. Так, например, с помощью MBA можно создавать зоны некроза диаметром до 8 см в течение очень короткого времени, а также выполнять абляцию опухолей, прилежащих к сосудам диаметром до 10 мм! Использование ЧК дает возможность проводить лечение узлов тесно прилежащих к желчному пузырю, желудку или ободочной кишке, что в принципе невозможно выполнить с помощью РЧА. Однако, учитывая то, что практически все отдаленные результаты лечения были получены при проведении РЧА, этот метод на сегодняшний день является эталоном чрескожной абляции, с которым принято сравнивать все другие виды абляции. Но говоря об РЧА, как о наиболее изученном методе ЧЭА необходимо иметь в виду возможность использования и других, более технологичных, методов энергетического воздействия, не имеющих пока такой же доказательной базы, какую имеет РЧА [23].

\section{2. Применение РЧА при ВCLC 0 и ВCLC А}

Ранее было показано, что РЧА обладает почти 100\% әффективностью для лечения узлов ГЦР диаметром менее 2 см (BCLC 0), а отдаленные результаты такого лечения практически не отличаются от результатов резекции печени. Поэтому, как уже было отмечено ранее, абляция должна рассматриваться как основная методика первой линии терапии у этой категории больных в том случае, если они не являются потенциальными кандидатами для трансплантации печени. Похожая ситуация складывается и при лечении пациентов со стадией BCLC A. У них РЧА должна применяться в первой линии терапии во всех случаях клинически значимой портальной гипертензии (HVPG более 10 мм. рт. ст), а также при наличии 2-3 узлов, тогда, когда не планируется выполнение трансплантации. В том случае если у пациента могут быть использованы две методики, РЧА и резекция, определенную роль в выборе метода терапии может играть локализация ГЦР. Так считается, что опухоли расположенные в глубине паренхимы печени значительно проще могут быть подвергнуты РЧА, чем хирургическому лечению. В то же время, ранее предполагалось, что эффективность абляции снижается при лечении опухолей, расположенных субкапсулярно, поэтому в данной ситуации предпочтение может быть отдано лапароскопической резекции. Однако недавно проведенные исследования показали отсутствие разницы между эффективностью РЧА субкапсулярных и интрапаренхиматозных опухолей. Кроме того, были разработаны эффективные методики гидродиссекции и наложения искусственного асцита, пневмоперитонеума или их комбинации, позволяющие в значительной степени повысить эффективность чрескожной абляции периферически-расположенных опухолей. Также были внедрены новые технологии визуализации, навигации и слияния изображений (в первую очередь с использованием ПДКТ), позволяющие выполнять абляцию опухолей диаметром около 1 см, в том числе и тех которые не визуализируются при УЗИ [26-29]. Это дополнительно расширило возможности ЧЭА делая ее проведение более прецизионным и эффективным.

Таким образом, согласно рекомендациям EASL 2018 РЧА должна рассматриваться как стандарт первой линии терапии у пациентов с BCLC 0. РЧА может применяться как альтернатива хирургической резекции у пациентов BCLC A при размере узлов до 3 см и их благоприятной локализации. И наконец, РЧА должна обязательно применяться (стандарт терапии) для лечения пациентов с BCLC 0 и BCLC A, которым по тем или иным причинам не может быть выполнена резекция и/или трансплантация печени.

\section{3. Применение ЧЭА при BCLC В}

В рекомендациях EASL 2018 допускается применение ЧЭА для лечения опухолей диаметром более 3 см, для лечения опухолей числом более трех (но диаметром менее $3 \mathrm{~cm}$ ), а также для лечения опухолей на фоне цирроза Child-Pugh B без признаков клинической декомпенсации. Результаты лечения (РЧА) опухолей диаметром более 3 см уступают по эффективности результатам лечения опухолей диаметром менее 3 см, однако использование РЧА считается оправданным, так как в любом случае улучшает продолжительность жизни больных. Особо хороших результатов удается добиться при сочетании методик ЧЭА и ТАХЭ. Комбинация ЧЭА и ТАХЭ значительно увеличивает выживаемость больных с крупными (диаметром более 3 см) узлами, без существенного роста числа осложнений.

\section{XII. ТАХЭ В ЛЕЧЕНИИ ГЦР [31, 34]}

\section{1. ТАХЭ как стандарт терапии промежуточной стадии ГЦР}

В стадию BCLC В включены все бессимптомные одиночные или множественные нерезектабельные узлы ГЦР без внепеченочного распространения и признаков инвазии в крупные сосуды (PV3/4). Недавно выполненный систематический обзор лечения 10108 человек показал, что объективная частота ответа после ТАХЭ в группе BCLC В составляет 52,5\%, медиана выживаемости - 19,4 мес., а общая выживаемость в течение 1, 2, 3 и 5 лет - 70,3\%, 51,8\%, 40,4\% и 32,4\%, соответственно [31]. Однако, поскольку данная группа пациентов (BCLC B) является очень разнородной (по числу узлов, по объему поражения и по функциональ- 
ному состоянию печени), существует необходимость выделения прогностически-благоприятной подгруппы пациентов. Согласно имеющейся информации, оптимальными кандидатами для ТАХЭ являются бессимптомные пациенты с одиночным большим узлом или несколькими нерезектабельными узлами без признаков сосудистой инвазии любого уровня (PV1-PV4) и внепеченочных метастазов и при условии выраженности цирроза не более Child-Pugh B7. В современных исследованиях с применением суперселективных методик ТАХЭ, медиана выживаемости в этой группе больных составляет 40-50 мес.

\section{2. ТАХЭ и другие виды трансартериальной те- рапии}

В настоящее время для широкого использования в рекомендации EASL 2018 включены два вида TAХЭ кТАХЭ (или ссТАХЭ) и ЛНМ-ТАХЭ. Хотя в цели данного обзора не входит подробное описание технических особенностей различных методов лечения, необходимо отметить одну важную вещь. Методики ТАХЭ необходимо принщипиальным образом отличать от других видов трансартериальной терапии, таких как ТАХИ, ТАЭ, ТАХЛ, ТАХЛ+ТАЭ, «липиодолизации печени» и ТАРЭ, которые, как показали проведенные исследования, являются значительно менее эффективными и в настоящее время не рекомендуются для терапии ГЦР $[21,31,34,44]$. Основными отличиями ТАХЭ (кТАХЭ и ЛНМ-ТАХЭ) от вышеперечисленных методик является использование принщипа суперселективности вмешательства - целевой доставки химиоэмболизата непосредственно в опухолевые сосуды через специальный микрокатетер. Ко второй особенности относится обязательное выполнение окклюзии сосудистого русла опухоли, сочетающееся с одновременным введением противоопухолевого препарата. Как уже было отмечено ранее, в последние годы предложены еще более совершенные технологии ТАХЭ, такие как уТАХЭ, Б-ТАХЭ, ПК-ТАХЭ и ПВЛА-ТАХЭ. Ряд из них (уТАХЭ и Б-ТАХЭ) обладает противоопухолевым эффектом сопоставимым с эффективностью ЧЭА $[21,44]$. В настоящее время эти методики находятся на стадии дальнейшего клинического изучения.

\section{3. Повторные процедуры и отказ от ТАХЭ}

Внедрение в последние годы принципа суперселективности, повлекшего за собой увеличение числа полных ответов на ТАХЭ, привело к необходимости пересмотра режимов лечения. На сегодняшний момент нет никаких достоверных данных, доказывающих преимущество регулярных сессий ТАХЭ по сравнению с лечением «по необходимости», то есть при повторном появлении опухолевой васкуляризации. В то же время регулярные процедуры ТАХЭ (1 раз в 2 мес.) способствуют усилению печёночной недостаточности у большинства пациентов. Поэтому повторные процедуры в настоящее время рекоменду- ется проводить только тем пациентам, у которых по данным МСКТ или МРТ с внутривенным контрастированием выявляется остаточная жизнеспособная опухоль. Это же относится и к повторному появлению жизнеспособной опухоли в процессе динамического наблюдения после эффективной терапии. Отказ от продолжения ТАХЭ может быть обусловлен прогрессированием опухоли или резистентностью к терапии. Резистентность определяется как отсутствие выраженного опухолевого некроза после проведения двух процедур ТАХЭ. В этом случае в качестве второй линии регионарного лечения может быть выполнена ПК-ТАХЭ, или пациент должен быть переведен на системную терапию. Как показали недавние исследования, сочетание ТАХЭ с приемом Сорафениба, вопреки ожиданиям, не привело к улучшению отдаленных результатов лечения.

\section{4. Применение ТАХЭ вне рамок BCLC B}

Хотя ТАХЭ является стандартом лечения только промежуточной стадии ГЦР, в реальной жизни около 40\% процедур химиоэмболизации выполняется либо на более ранних, либо (реже) на более продвинутых стадиях. Даже в рамках клинических рекомендаций ТАХЭ используется значительно шире, чем только при стадии BCLC B. Как уже отмечалось ранее, ТАХЭ является необходимым компонентом терапии пациентов, находящихся на листе ожидания трансплантации, а также при проведении неоадъювантной терапии. Проведенные недавно исследования показали, что ТАХЭ представляет собой основную часть ежедневной клинической практики у пациентов с ГЦР во всем мире [21, 31, 34, 44].

\section{XIII. ЗАКЛЮЧЕНИЕ}

Таким образом, можно сделать вывод о том, что хирургические технологии (хирургические и рентгенохирургические методы лечения) играют ключевую роль в терапии ГЦР. Особенностью вирус-ассоциированного ГЦР является то, что он развивается в печени, пораженной циррозом. Неэффективность лучевой терапии и химиотерапии наряду со сложностями выполнения обширных хирургических вмешательств в цирротически-измененной печени породили в 1970-1980 годы острую необходимость поиска новых технологических решений, направленных на разработку минимально-инвазивных хирургических вмешательств. Совместный прогресс науки и техники произошедший в последние десятилетия и неустанный поиск новых возможностей привели к возникновению четвертого направления противоопухолевой терапии (лишенной в значительной степени недостатков классической хирургии) - интервенционной онкологии, рожденной на стыке хирургии, онкологии и лучевой диагностики. Внедрение новых минимально-инвазивных методов 
лечения, таких как ЧЭА и ТАХЭ, наряду с большими успехами медицинской визуализации и классической хирургии позволили в настоящее время существенно увеличить продолжительность жизни больных очень ранним, ранним и промежуточным раком печени, что было неоднократно продемонстрировано в различных рандомизированных исследованиях. Более того, разработанные для лечения ГЦР рентгенохирургические (интервенционно- радиологические) методики, такие как РЧА, МВА, ЧК, ТАХЭ и др., в настоящее время все шире применяются для лечения и других солидных опухолей. Залогом эффективности (и возможности) использования хирургических технологий для лечения ГЦР является как можно более ранняя диагностика этого грозного заболевания у пациентов группы риска, а также своевременное лечение вирусного гепатита и связанного с ним цирроза печени.

\section{Список литературы}

1. Plummer M., de Martel C., Vignat J., Ferlay J., Bray F., Franceschi S. Global burden of cancers attributable to infections in 2012: a synthetic analysis // Lancet Glob Health. - 2016. - Vol. 4, №9. - P. e609-16.

2. Lunn R.M., Jabnke G.D., Rabkin C.S. Tumour virus epidemiology // Philos Trans R Soc Lond B Biol Sci. - 2017. Vol. 372, №1732. - P. pii: 20160266.

3. White M.K., PaganoJ.S., Khalili K. Viruses and human cancers: a long road of discovery of molecular paradigms // Clin Microbiol Rev. - 2014. - Vol. 27, №3. - P. 463-81.

4. Кит О.И., Шапошников А.В. Гепатоцеллюлярный рак: Классификация методов хирургического лечения // Анналы хирургической гепатологии. - 2012. - Т. 17, №3. - С. 104-109.

5.BrayF., FerlayJ., Soerjomataram I., Siegel R.L., Torre L.A.,JemalA. Global cancer statistics 2018: GLOBOCAN estimates of incidence and mortality worldwide for 36 cancers in 185 countries // CA Cancer J Clin. - 2018. - Vol. 68, №6. - P. 394-424. 6. Balogh J., Victor D. 3rd., Asham E.H., Burroughs S.G., Boktour M., Sabaria A., Li X., Ghobrial R.M., Monsour H.P. Jr. Hepatocellular carcinoma: a review // J Hepatocell Carcinoma. - 2016. - Vol. 3. - P. 41-53. eCollection 2016.

7. Mak L.Y., Cruz-Ramón V., Chinchilla-López P., Torres H.A., LoConte N.K., Rice J.P., Foxhall L.E., Sturgis E.M., Merrill J.K., Bailey H.H., Méndez-Sánchez N., Yuen M.F., HwangJ.P. Global Epidemiology, Prevention, and Management of Hepatocellular Carcinoma // Am Soc Clin Oncol Educ Book. - 2018. - №38. - P. 262-279.

8. Официальный сайт The Global Cancer Observatory (GLOBOCAN 2018) Международного Агентства по Изучению Рака (International Agency for Research of Cancer, IARC). - [Электронный pecypc] - URL: https://gco. iarc.fr/today/data/factsheets/cancers/11-Liver-fact-sheet.pdf. Дата обращения: 14.11.2018.

9. Официальный сайт The Global Cancer Observatory (GLOBOCAN 2018) Международного Агентства по Изучению Рака (International Agency for Research of Cancer, IARC). - [Электронный ресурc] - URL: https://gco. iarc.fr/today/online-analysis-map?v=2018. Дата обращения: 14.11.2018.

10. Бредер В.В., Косырев В.Ю., Кудашкин Н.Е., Лактионов К.К. Гепатоцеллюлярный рак в Российской Федерации как социальная и медицинская проблема // Медицинский совет. - 2016. - №10. - С. 10-18.

11. Каприн А.Д., Старинский В.В., Петрова Г.В. Злокачественные образования в России в 2017 году (Заболеваемость и смертность). - Москва: РИИС ФИАН. - 2018. - 250 с.

12. Maucort-Boulch D., de Martel C., Franceschi S., Plummer M. Fraction and incidence of liver cancer attributable to hepatitis B and C viruses worldwide // Int J Cancer. - 2018. - Vol. 142, №12. - P. 2471-2477.

13. Ringelhan M., McKeatingJ.A., Protzer U. Viral hepatitis and liver cancer // Philos Trans R Soc Lond B Biol Sci. 2017. - Vol. 372, №1732. - P. pii: 20160274.

14. Tsochatzis E.A., Bosch J., Burroughs A.K. Liver cirrhosis // Lancet. - 2014. - Vol. 383, №9930. - P. 1749-61.

15. Garcia-Tsao G., Friedman S., Iredale J., Pinzani M. Now there are many (stages) where before there was one: In search of a pathophysiological classification of cirrhosis // Hepatology. - 2010. - Vol. 51, №4. - P. 1445-9.

16. Suk K.T., Kim D.J. Staging of liver fibrosis or cirrhosis: The role of hepatic venous pressure gradient measurement // World J Hepatol. - 2015. - Vol. 7, №3. - P. 607-15.

17. Kim M.Y., Jeong W.K., Baik S.K. Invasive and non-invasive diagnosis of cirrhosis and portal hypertension // World J Gastroenterol. - 2014. - Vol. 20, №15. - P. 4300-15.

18. De Baere T. The IR Evolution in Oncology: Tools, Treatments, and Guidelines // Cardiovasc Intervent Radiol. 2017. - Vol. 40, №1. - P. 3-8.

19. Rösch J., Keller F.S., Kaufman J.A. The birth, early years, and future of interventional radiology // J Vasc Interv Radiol. - 2003. - Vol. 14, №7. - P. 841-53.

20. Takayasu K., Shima Y., Muramatsu Y., Moriyama N., Yamada T., Makuuchi M., Hasegawa H., HirohashiS. Hepatocellular carcinoma: treatment with intraarterial iodized oil with and without chemotherapeutic agents // Radiology. 1987. - Vol. 163, №2. - P. 345-51.

21.Imai N., Ishigami M., Ishizu Y., Kuzuya T., Honda T., Hayashi K., Hirooka Y., Goto H. Transarterial chemoembolization for hepatocellular carcinoma: A review of techniques // World J Hepatol. - 2014. - Vol. 6, №12. - P. 844-50.

22. Chao M., Wu H., Jin K., Li B., Wu J., Zhang G., Yang G., Hu X. A nonrandomized cohort and a randomized study of local control of large hepatocarcinoma by targeting intratumoral lactic acidosis // Elife. - 2016. - Vol. 5. - P. pii: e15691.

23. Балахнин П.В., Шмелев А.С., Шачинов Е.Г. Чрескожная энергетическая абляция опухолей: Принципы, технологии, результаты // Практическая онкология. - 2016. - Т. 17, №3. - С. 129-153. 
24. Narsinb K.H., CuiJ., Papadatos D., Sirlin C.B., Santillan C.S. Hepatocarcinogenesis and LI-RADS // Abdom Radiol (NY). - 2018. - Vol. 43, №1. - P. 158-168.

25. Sparchez Z., Mocan T. Contemporary role of liver biopsy in hepatocellular carcinoma // World J Hepatol. 2018. - Vol. 10, №7. - P. 452-461.

26. Cazzato R.L., Buy X., Alberti N., Fonck M., Grasso R.F., Palussière J. Flat-panel cone-beam CT-guided radiofrequency ablation of very small $(\leq 1,5 \mathrm{~cm})$ liver tumors: technical note on a preliminary experience // Cardiovasc Intervent Radiol. - 2015. - Vol. 38, №1. - P. 206-12.

27. Floridi C., Radaelli A., Abi-Jaoudeb N., Grass M., Lin M., Chiaradia M., Geschwind J.F., Kobeiter H., Squillaci E., Maleux G., Giovagnoni A., Brunese L., Wood B., Carrafiello G., Rotondo A. C-arm cone-beam computed tomography in interventional oncology: technical aspects and clinical applications // Radiol Med. - 2014. - Vol. 119, №7. - P. 521 - 32.

28. Abi-Jaoudeb N., Venkatesan A.M., Van der Sterren W., Radaelli A., Carelsen B., Wood B.J. Clinical experience with cone-beam CT navigation for tumor ablation // J Vasc Interv Radiol. - 2015. - Vol. 26, №2. - P. 214-9.

29. Sánchez Y., Anvari A., Samir A.E., Arellano R.S., Prabbakar A.M., Uppot R.N. Navigational Guidance and Ablation Planning Tools for Interventional Radiology // Curr Probl Diagn Radiol. - 2017. - Vol. 46, №3. - P. $225-233$.

30. Hansmann J., Ray C.E. Jr. Overview of Staging Systems for Hepatocellular Carcinoma and Implications for Interventional Radiology // Semin Intervent Radiol. - 2017. - Vol. 34, №2. - P. 213-219.

31. European Association for the Study of the Liver. EASL Clinical Practice Guidelines: Management of hepatocellular carcinoma // J Hepatol. - 2018. - Vol. 69, №1. - P. 182-236.

32. Omata M., Cheng A.L., Kokudo N., Kudo M., Lee J.M., Jia J., Tateishi R., Han K.H., Chawla Y.K., Shiina S., Jafri W., Payawal D.A., Obki T., Ogasawara S., Chen P.J., Lesmana C.R.A., Lesmana L.A., Gani R.A., Obi S., Dokmeci A.K., Sarin S.K. Asia-Pacific clinical practice guidelines on the management of hepatocellular carcinoma: a 2017 update // Hepatol Int. - 2017. - Vol. 11, №4. - P. 317-370.

33. Song P., Cai Y., Tang H., Li C., HuangJ. The clinical management of hepatocellular carcinoma worldwide: A concise review and comparison of current guidelines from 2001 to 2017 // Biosci Trends. - 2017. - Vol.11, №4. - P. 389-398.

34. Forner A., Reig M., Bruix J. Hepatocellular carcinoma // Lancet. - 2018. - Vol. 391, №10127. - P. $1301-1314$.

35. Бредер В.В., Патютко Ю.И., Перегудова М.В., Косырев В.Ю., Кудашкин Н.Е., Романова К.А., Лактионов К.К. Сравнительный анализ современных систем стадирования гепатоцеллюлярного рака - TNM/ AJCC, CUPI, CLIP и BCLC в Российской онкологической практике. Опыт Российского онкологического научного центра им. Н.Н. Блохина // Злокачественные опухоли. - 2016. - №2 (18). - С. 26-34.

36. Tustumi F., Ernani L., Coelho F.F., Bernardo W.M., Junior S.S., Kruger J.A.P., Fonseca G.M., Jeismann V.B., Cecconello I., Herman P. Preoperative strategies to improve resectability for hepatocellular carcinoma: a systematic review and meta-analysis // HPB (Oxford). - 2018. - Vol. 26. - pii: S1365-182X(18)32648-0.

37. Holzwanger D.J., MadoffD.C. Role of interventional radiology in the management of hepatocellular carcinoma: current status // Chin Clin Oncol. - 2018. - Vol. 7, №5. - P. 49.

\section{References}

1.Plummer M., de Martel C., Vignat J., Ferlay J., Bray F., Franceschi S. Global burden of cancers attributable to infections in 2012: a synthetic analysis. Lancet Glob Health. 2016 Sep; 4(9): e609-16. doi: 10.1016/S2214-109X(16)30143-7.

2. Lunn R.M., Jabnke G.D., Rabkin C.S. Tumour virus epidemiology. Philos Trans R Soc Lond B Biol Sci. 2017 Oct 19; 372(1732): pii: 20160266. doi: 10.1098/rstb.2016.0266.

3. White M.K., Pagano J.S., Khalili K. Viruses and human cancers: a long road of discovery of molecular paradigms. Clin Microbiol Rev. 2014 Jul; 27(3): 463-81. doi: 10.1128/CMR.00124-13.

4. Kit O.I., Shaposhnikov A.V. Hepatocellular Carcinoma. Surgical Management Classifications. Annaly khirurgicheskoy gepatologii (Annals HPB Surgery). 2012; 17(3): 104-109. (In Russ)

5. Bray F., Ferlay J., Soerjomataram I., Siegel R.L., Torre L.A., Jemal A. Global cancer statistics 2018: GLOBOCAN estimates of incidence and mortality worldwide for 36 cancers in 185 countries. CA Cancer J Clin. 2018 Nov; 68(6): 394-424. doi: 10.3322/caac. 21492.

6. Balogh J., Victor D. 3rd., Asham E.H., Burroughs S.G., Boktour M., Sabaria A., Li X., Gbobrial R.M., Monsour H.P. Jr. Hepatocellular carcinoma: a review. J Hepatocell Carcinoma. 2016 Oct 5; 3: 41-53. eCollection 2016.

7. Mak L.Y., Cruz-Ramón V., Chinchilla-López P., Torres H.A., LoConte N.K., Rice J.P., Foxball L.E., Sturgis E.M., Merrill J.K., Bailey H.H., Méndez-Sánchez N., Yuen M.F., HwangJ.P. Global Epidemiology, Prevention, and Management of Hepatocellular Carcinoma. Am Soc Clin Oncol Educ Book. 2018 May 23; (38): 262-279. doi: 10.1200/EDBK 200939.

8. Official site of Global Cancer Observatory (GLOBOCAN 2018) of International Agency for Research of Cancer, IARC. Available at: https:/gco.iarc.fr/today/data/factsheets/cancers/11-Liver-fact-sheet.pdf. Accessed at: November 14, 2018.

9. Official site of Global Cancer Observatory (GLOBOCAN 2018) of International Agency for Research of Cancer, IARC. Available at: https://gco.iarc.fr/today/online-analysis-map?v=2018. Accessed at: November 14, 2018.

10. Breder V.V., Kosyrev V.Y., Kudashkin N.E., Laktionov K.K. Hepatocellular carcinoma as a social and medical problem in the Russian Federation. Meditsinsky sovet (Medical Council). 2016; 17(3): 104-109. (In Russ). doi: 10.21518/2079701X-2016-10-10-16.

11. Kaprin A.D., Starinskij V.V., Petrova G.V. Malignant tumors in Russia in 2017 (morbidity and mortality). 2018; Moscow: RIIS FIAN. 250 p. (In Russ)

12. Maucort-Boulch D., de Martel C., Franceschi S., Plummer M. Fraction and incidence of liver cancer attributable to hepatitis B and C viruses worldwide. Int J Cancer. 2018 Jun 15; 142(12): 2471-2477. doi: 10.1002/ijc.31280.

13. Ringelhan M., McKeatingJ.A., Protzer U. Viral hepatitis and liver cancer. Philos Trans R Soc Lond B Biol Sci. 2017 Oct 19; 372(1732). pii: 20160274. doi: 10.1098/rstb.2016.0274. 
14. Tsochatzis E.A., Bosch J., Burroughs A.K. Liver cirrhosis. Lancet. 2014 May 17; 383(9930): 1749-61. doi: 10.1016/ S0140-6736(14)60121-5.

15. Garcia-Tsao G., Friedman S., Iredale J., Pinzani M. Now there are many (stages) where before there was one: In search of a pathophysiological classification of cirrhosis. Hepatology. 2010 Apr; 51(4): 1445-9. doi: 10.1002/hep.23478.

16. Suk K.T., Kim D.J. Staging of liver fibrosis or cirrhosis: The role of hepatic venous pressure gradient measurement. World J Hepatol. 2015 Mar 27; 7(3): 607-15. doi: 10.4254/wjh.v7.i3.607.

17. Kim M.Y., Jeong W.K., Baik S.K. Invasive and non-invasive diagnosis of cirrhosis and portal hypertension. World J Gastroenterol. 2014 Apr 21; 20(15): 4300-15. doi: 10.3748/wjg.v20.i15.4300.

18. De Baere T. The IR Evolution in Oncology: Tools, Treatments, and Guidelines. Cardiovasc Intervent Radiol. 2017 Jan; 40(1): 3-8. doi: 10.1007/s00270-016-1503-2.

19. Rösch J., Keller F.S., Kaufman J.A. The birth, early years, and future of interventional radiology. J Vasc Interv Radiol. 2003 Jul; 14(7): 841-53.

20. Takayasu K., Shima Y., Muramatsu Y., Moriyama N., Yamada T., Makuuchi M., Hasegawa H., Hirohashi S. Hepatocellular carcinoma: treatment with intraarterial iodized oil with and without chemotherapeutic agents. Radiology. 1987 May; 163(2): 345-51.

21.Imai N., Ishigami M., Ishizu Y., Kuzuya T., Honda T., Hayashi K., Hirooka Y., Goto H. Transarterial chemoembolization for hepatocellular carcinoma: A review of techniques. World J Hepatol. 2014 Dec 27; 6(12): 844-50. doi: 10.4254/wjh. v6.i12.844.

22. Chao M., Wu H., Jin K., Li B., Wu J., Zhang G., Yang G., Hu X. A nonrandomized cohort and a randomized study of local control of large hepatocarcinoma by targeting intratumoral lactic acidosis. Elife. 2016 Aug 2; 5. pii: e15691. doi: $10.7554 /$ eLife.15691.

23. Balakhnin P.V., Shmelev A.S., Shachinov E.G. Percutaneous energy-based tumor ablation: principles, technologies, results. Prakticheskaja onkologija (Practical Oncology). 2016; 17(3): 129-153. (In Russ)

24. Narsinh K.H., Cui J., Papadatos D., Sirlin C.B., Santillan C.S. Hepatocarcinogenesis and LI-RADS. Abdom Radiol (NY). 2018 Jan; 43(1): 158-168. doi: 10.1007/s00261-017-1409-8.

25. Sparchez Z., Mocan T. Contemporary role of liver biopsy in hepatocellular carcinoma. World J Hepatol. 2018 Jul 27; 10(7): 452-461. doi: 10.4254/wjh.v10.i7.452.

26. Cazzato R.L., Buy X., Alberti N., Fonck M., Grasso R.F., Palussière J. Flat-panel cone-beam CT-guided radiofrequency ablation of very small $(\leq 1,5 \mathrm{~cm})$ liver tumors: technical note on a preliminary experience. Cardiovasc Intervent Radiol. 2015 Feb; 38(1): 206-12. doi: 10.1007/s00270-014-1019-6.

27. Floridi C., Radaelli A., Abi-Jaoudeb N., Grass M., Lin M., Chiaradia M., Geschwind J.F., Kobeiter H., Squillaci E., Maleux G., Giovagnoni A., Brunese L., Wood B., Carrafiello G., Rotondo A. C-arm cone-beam computed tomography in interventional oncology: technical aspects and clinical applications. Radiol Med. 2014 Jul; 119(7): 521-32. doi: 10.1007/s11547-014-0429-5.

28. Abi-Jaoudeh N., Venkatesan A.M., Van der Sterren W., Radaelli A., Carelsen B., Wood B.J. Clinical experience with cone-beam CT navigation for tumor ablation. J Vasc Interv Radiol. 2015 Feb; 26(2): 214-9. doi: 10.1016/j. jvir.2014.10.049.

29. Sánchez Y., Anvari A., Samir A.E., Arellano R.S., Prabbakar A.M., Uppot R.N. Navigational Guidance and Ablation Planning Tools for Interventional Radiology. Curr Probl Diagn Radiol. 2017 May-Jun; 46(3): 225-233. doi: 10.1067/j. cpradiol.2016.11.002.

30. Hansmann J., Ray C.E. Jr. Overview of Staging Systems for Hepatocellular Carcinoma and Implications for Interventional Radiology. Semin Intervent Radiol. 2017 Jun; 34(2): 213-219. doi: 10.1055/s-0037-1602757.

31. European Association for the Study of the Liver. EASL Clinical Practice Guidelines: Management of hepatocellular carcinoma. J Hepatol. 2018 Jul; 69(1): 182-236. doi: 10.1016/j.jhep.2018.03.019.

32. Omata M., Cheng A.L., Kokudo N., Kudo M., Lee J.M., Jia J., Tateishi R., Han K.H., Chawla Y.K., Shiina S., Jafri W., Payawal D.A., Obki T., Ogasawara S., Chen P.J., Lesmana C.R.A., Lesmana L.A., Gani R.A., Obi S., Dokmeci A.K., Sarin S.K. Asia-Pacific clinical practice guidelines on the management of hepatocellular carcinoma: a 2017 update. Hepatol Int. 2017 Jul; 11(4): 317-370. doi: 10.1007/s12072-017-9799-9.

33. Song P., Cai Y., Tang H., Li C., Huang J. The clinical management of hepatocellular carcinoma worldwide: a concise review and comparison of current guidelines from 2001 to 2017. Biosci Trends. 2017; 11(4): 389-398. doi: 10.5582 /bst.2017.01202.

34. Forner A., Reig M., Bruix J. Hepatocellular carcinoma. Lancet. 2018 Mar 31;391(10127): 1301-1314. doi: 10.1016/ S0140-6736(18)30010-2.

35. Breder V.V., Patiutko Y.I., Peregudova M.V., Kosirev V.Y., Kudashkin N.E., Romanova K.A., Laktionov K.K. Comparative analysis of the modern staging systems of hepatocellular carcinoma - TNM/ AJCC, CUPI, CLIP and BCLC from everyday clinical practice in Russia. The experience of Russian oncological scientific center n.a. N.N. Blokhin. Malignant tumours. 2016; 2 (18): 26-34. (In Russ)

36. Tustumi F., Ernani L., Coelho F.F., Bernardo W.M., Junior S.S., Kruger J.A.P., Fonseca G.M., Jeismann V.B., Cecconello I., Herman P. Preoperative strategies to improve resectability for hepatocellular carcinoma: a systematic review and meta-analysis. HPB (Oxford). 2018 Jul 26: pii: S1365-182X(18)32648-0. doi: 10.1016/j.hpb.2018.06.1798.

37. Holzwanger D.J., MadoffD.C. Role of interventional radiology in the management of hepatocellular carcinoma: current status. Chin Clin Oncol. 2018 Oct; 7(5): 49. doi: 10.21037/cco.2018.07.04. 